\title{
OTÁZKA ZEMĚDĚLSTVÍ A POTRAVINÁŘSKÉ PRODUKCE STŘEDOVĚKÝCH HORNICKÝCH KOMUNIT
}

\author{
KRYŠTOF DERNER - PETR HRUBÝ
}

\begin{abstract}
Abstrakt: Předmětem studie je otázka obživy a vlastní zemédělské produkce středověkých hornických komunit. Informace o chovu dobytka a spotřebě potravin obsahuji báňské zákoníky a dalši právni prameny 13. a 14. století. Cenné poznatky v podobě archeobotanických a archeozoologických dat přinášeji v posledních letech archeologické výzkumy zaniklých hornických osad na přemyslovském území. Při komplexním př́stupu si lze přinejmenším položit otázku, zda byl z hlediska spotřeby potravin režim jejich hospodářství zcela pasivní, konzumní, a tedy plně závislý na okolni zemědělské produkční sféré, či zda měl charakter subsistenčního hospodaření. Autoři se pozastaví i nad doloženým zvírectvem v hornických osadách z hlediska produkce potravin vs. účelového chovu tahounů pro práci v dolech, v úpravnách a v dopravě.
\end{abstract}

Klićová slova: středověká hornická sídliště-produkce potravin-subsistence-archeobotanika-archeozoologie.

\section{Farming and food production in medieval mining communities}

Abstract: This study focuses on the issue of subsistence and farming production in medieval mining communities. Information about the breeding of cattle and food consumption can be found in mining codes of law and other legal sources from the 13th and 14th centuries. In recent years, valuable information in the form of archaeobotanical and archaeozoological data has been provided by archaeological research into deserted mining settlements on a territory owned by tbe Premyslid dynasty. With this comprehensive approach, we can ask whether the form of their agriculture was completely passive and consumerist in regard to food consumption, and thus fully dependent on nearby production areas, or whether it had the character of self-subsistent economy. The authors also discuss animals associated with mining settlements from the perspective of food production vs. breeding horses for work in the mines and cleaning shops and for transport.

Key words: medieval mining settlement-food production - subsistence-archaeobotany-archaeozoology.

\section{1 Úvod}

\subsection{Co jsou to středověká hornická sídliště}

Při úvahách nad obživou obyvatel středověkých hornických osad nebylo možné pracovat výlučně s dílčími archeologickými situacemi, u nichž se dá uvažovat o př́ímé souvislosti s uskladněním a zpracováváním potravin. Téma, které se zdánlivě mohlo podobat nenáročnému pojednání o každodennosti, se ukázalo mnohem složitější. Přri pokusu o jeho uchopení nebylo možné vyhnout se principiálním otázkám samotné podstaty existence středověkých hornických osad.

Hornické osady jsou na rozdíl od zemědělských vesnic, ale i měst, především prosperitními sídlišti specifických skupin středověkého obyvatelstva, jejichž právní a sociální status byl definován profesně. V určitém smyslu je možné označit je za specializované osady pracovní. Právě to bylo prŕčinou specifik, kterými se jejich obyvatelstvo jak od obyvatel měst, tak od venkovského obyvatelstva odlišovalo. Existence těchto sídlišt' je př́mo podmíněná existencí důlních, úpravnických a hutních provozů. Faktory určujícími množství, lidnatost a rozlohu těchto osad byly četnost a vydatnost rudonosných struktur a potažmo objem a tempo důlní činnosti. Tím bylo určeno i množství lidí v navázaných profesích (uhliřství, dřevařství, kovářství, důlní tesařství apod.). Z tohoto důvodu je existence těchto sídlišst ve srovnání se soudobými agrárními sídlišti krátkodobá: existovala jen několik pracovních sezón, ve výjimečných případech i desítku let, generaci, možná déle. Zakládání hornických osad ve 13. století proto kulminuje spolu s objemem hornické činnosti po polovině 13. století. 
Hlavním teoretickým problémem je schopnost či neschopnost hornických sídlišt' uživit se vlastní potravinářskou výrobou. Je jasné, že hornická sídliště jsou z hlediska své produkce principiálně jasně neagrární. Kdybychom ale vlastní potravinářskou produkci úplně vyloučili, představovala by hornická sídliště výjimku v systému obživy aglomerací, které se ještě nemohly spolehnout na stabilní trh s potravinami (Klír 2010, 374). To odporuje teorii nedokonale fungujícího trhu, v němž i města usilují o maximální míru subsistence. Nerozvinutý trh ještě nezaručoval přežití hornických center, vidíme však snahu řídících struktur o podporu důlního sektoru v podobě privilegií ke zřízení krámů, šenků, přímého zásobování atd. Klíčovou otázkou je tedy podíl zásobování hornických center potravinami a podíl, jakož i charakter jejich vlastní produkce, u níž předpokládáme, že byla spíše menšinová.

Studie pracuje především se středověkými hornickými areály 13. a 14. století na přemyslovském území, které byly v posledních deseti letech podrobeny archeologickému výzkumu, popřípadě průzkumům, a které poskytují údaje o topografii a infrastruktuře a údaje archeobotanické, popř́ípadě archeozoologické. Referovány jsou areály ve dvou historických hornických

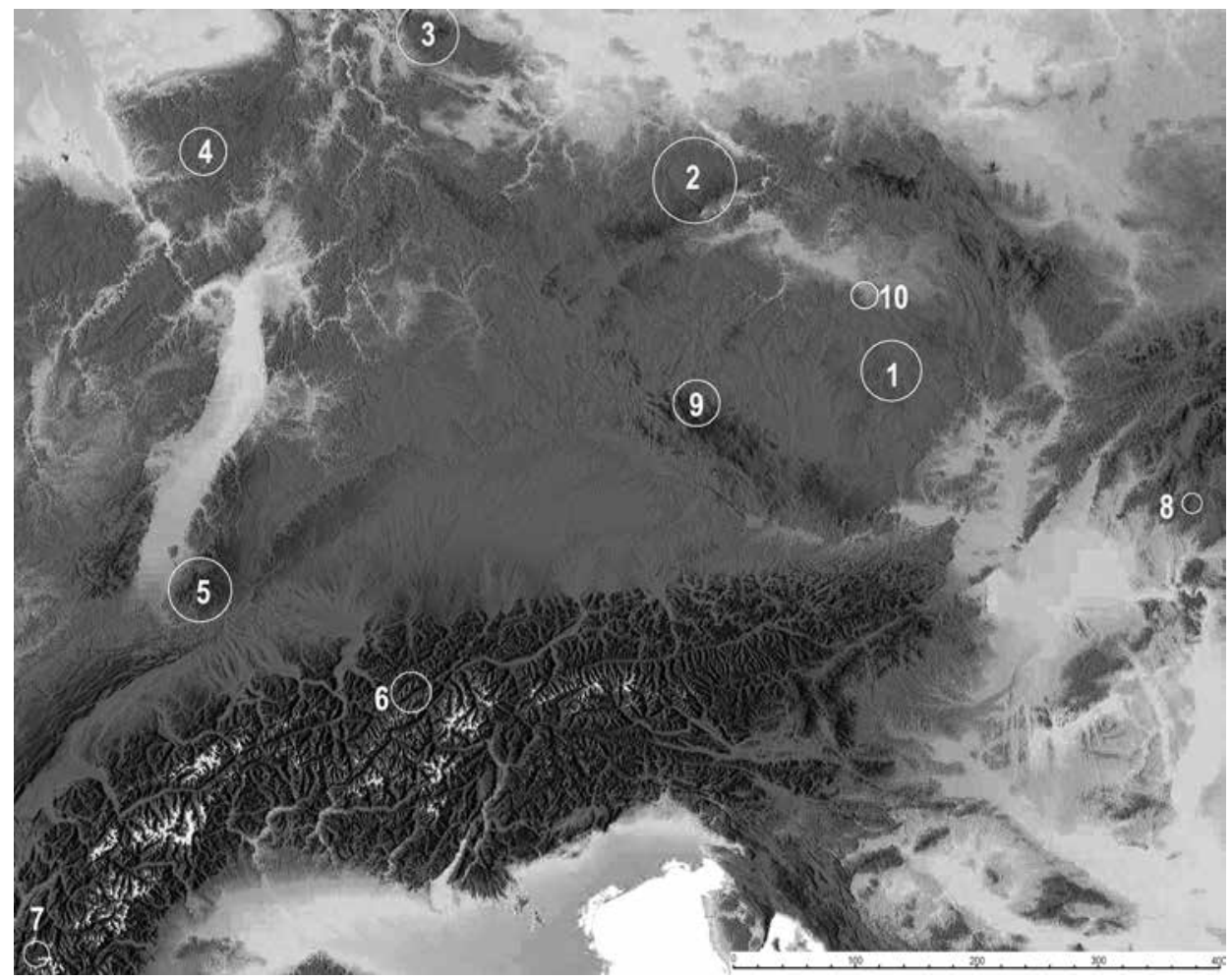

Obr. 1. Mapa s vyznačením českých hornických regionů s pojednávanými lokalitami a soudobých evropských hornických regionů s lokalitami užitými jako analogie. 1 - Českomoravská vrchovina (lokality Staré Hory, Utín, Cvilínek, Vyskytná); 2 - Krušné Hory / Erzgebirge (lokality Kremsiger, Starý Zámek, Dippoldiswalde, Treppenhauer, Hohenforst); 3 - Harz, lokalita Johaneser Kurhaus, Clausthal-Zellerfeld; 4 -Siegerland, lokalita Altenberg; 5 - Schwarzwald (lokality Sulzburg, Schauinsland, Birkenberg); 6 - Silbertal, lokalita Kristberg; 7 - oblast Huez, lokalita Brandes en Oisans; 8 - Štiavnické vrchy, lokalita Glanzenberg, Banská Štiavnica; 9 - Šumava, lokalita Kašperské Hory; 10 - Kutná Hora.

Abb. 1. Karte mit eingezeichneten böhmischen Bergbauregionen und den behandelten Fundstellen sowie zeitgenössische europäische Bergbauregionen mit als Analogien herangezogenen Fundstellen. 1 - Böhmisch-Mährische Höhe (Fundstellen Staré Hory, Utín, Cvilínek, Vyskytná); 2 - Erzgebirge (Fundstellen Kremsiger, Starý Zámek, Dippoldiswalde, Treppenhauer, Hohenforst); 3 - Harz, Fundstelle Johaneser Kurhaus, Clausthal-Zellerfeld; 4 - Siegerland, Fundstelle Altenberg; 5 - Schwarzwald (Fundstellen Sulzburg, Schauinsland, Birkenberg); 6 - Silbertal, Fundstelle Kristberg; 7 - Gebiet Huez, Fundstelle Brandes en Oisans; 8 - Schemnitzer Berge, Fundstelle Glanzenberg, Banská Štiavnica/Schemnitz; 9 - Böhmerwald, Fundstelle Kašperské Hory/Bergreichenstein; 10 - Kutná Hora/Kuttenberg. 
regionech. Prvním regionem je centrální Českomoravská vrchovina s důlními středisky Jihlava - Staré Hory, Cvilinek, Vyskytná a Utín. I zde mohou být při jejich analogickém srovnávání použita další zaniklá soudobá centra v regionu, ovšem jen v úrovni doplňující (obr. 2, obr. 5-8). Druhou oblastí jsou Krušné hory s hornickým sídlištěm Kremsiger a s menším výrobním areálem Starý Zámek u Př́sečnice. V širším územním kontextu jsou tu více, tu méně pojednávána další zaniklá krušnohorská stř̌ediska na saské straně hranice (obr. 3, 4, 9-10). Ve výkladu, který se snaží zasadit referované lokality v obou regionech do evropských souvislostí, jsou pak přirozeně použity př́klady analogických hornických sídlišt' i z jiných oblastí historické produkce drahých kovů v Evropě (obr. 1).

\subsection{Topografický a archeologický obraz zaniklých hornických osad}

Hornické osady jsou v rudních oblastech vedle agrárních sídel druhým nejrozšířenějším prvkem zaniklé sídelní struktury stř̌edověku. Nejpodstatnější rozdíl mezi zemědělskými

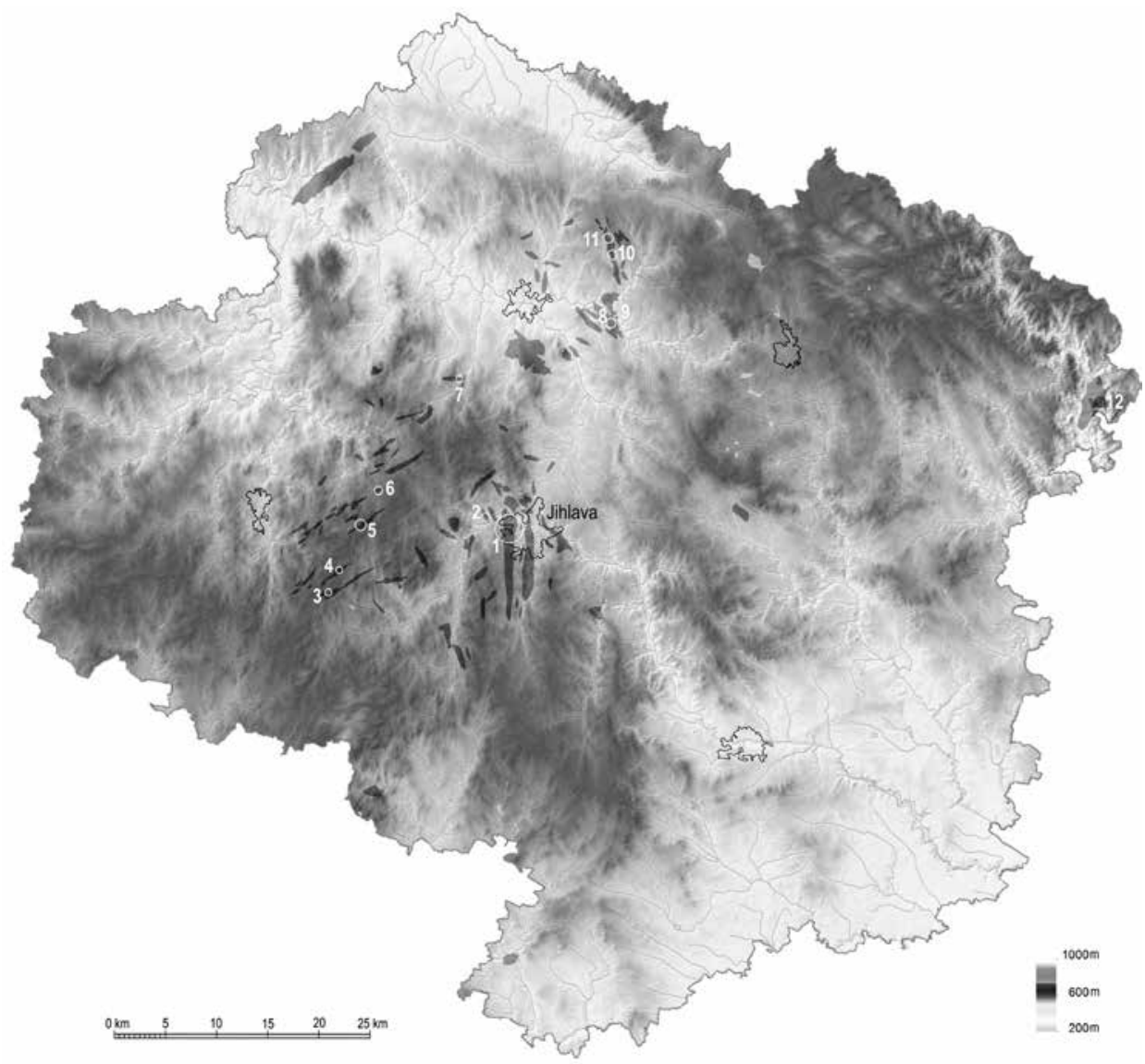

Obr. 2. Českomoravská vrchovina v hranicích kraje Vysočina s vyznačením referovaných hornických sídlišt’. 1 - Jihlava Staré Hory; 3 - Cvilínek, obec Černov a Chrástov, okr. Pelhřimov; 5 - Vyskytná, okr. Pelhřimov; 8 - Poperek/Buchberg, obec Utín, okr. Havlíčủv Brod. 2, 4, 6 a 7 - nejsou referovaná sídliště.

Abb. 2. Böhmisch-Mährische Höhe in den Grenzen der Region Hochland/Kraj Vysočina mit eingezeichneten erörterten Bergbausiedlungen. 1 - Jihlava - Staré Hory; 3 - Cvilínek, Gemeinde Černov und Chrástov, Bezirk Pelhřimov; 5 - Vyskytná, Bezirk Pelhřimov; 8 - Poperek/Buchberg, Gemeinde Utín, Bezirk Havlíčův Brod. 2, 4, 6 und 7 sind Siedlungen, die nicht erörtert wurden. 


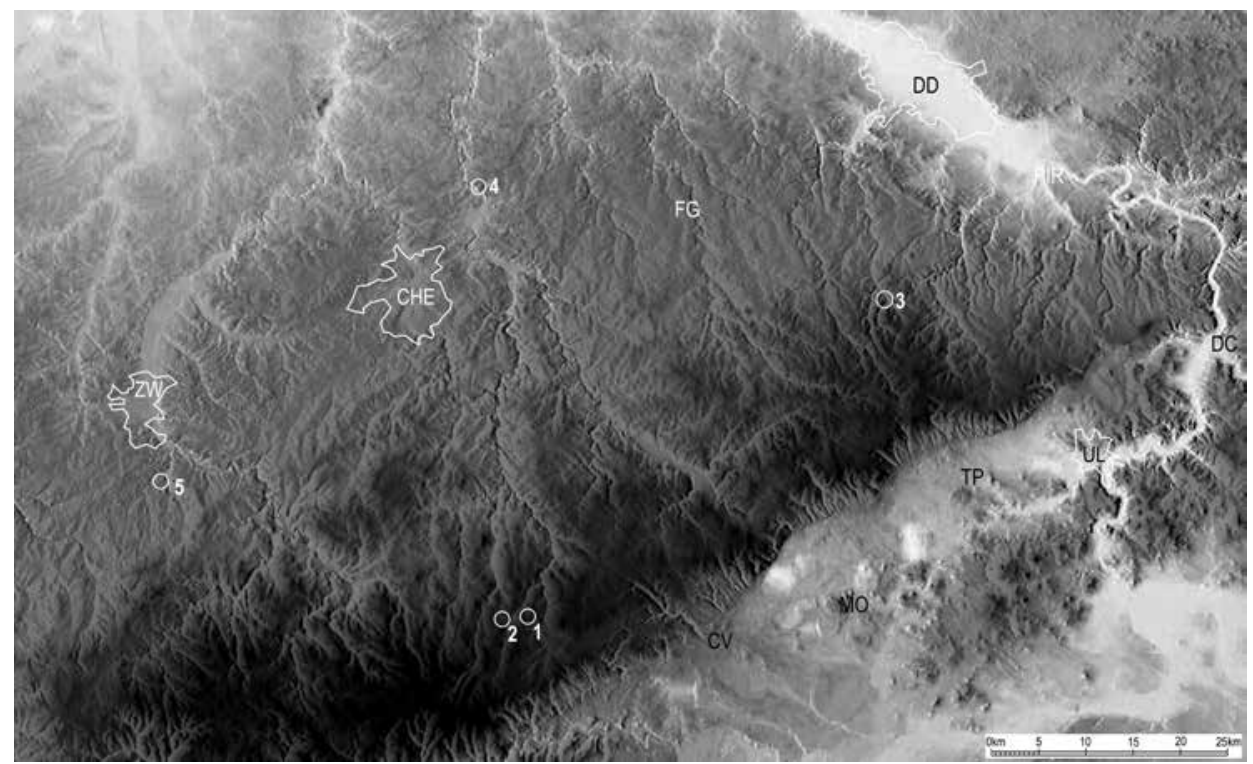

Obr. 3. Krušné hory s vyznačením referovaných lokalit, nebo analogických lokalit. 1 - Kremsiger, k. ú. Př́ísečnice, okr. Chomutov; 2 - Starý Zámek, k. ú. Černý Potok, okr. Chomutov; 3 - Dippoldiswalde, Sasko; 4 - Treppenhauer, město Frankenberg, Sasko; 5 - Hohenforst, obec Kirchberg, Sasko.

Abb. 3. Erzgebirge mit eingezeichneten erörterten oder analogen Fundstellen. 1 - Kremsiger, Katastergebiet Př́ísečnice, Bezirk Chomutov; 2 - Starý Zámek, Katastergebiet Černý Potok, Bezirk Chomutov; 3 - Dippoldiswalde, Sachsen; 4 - Treppenhauer, Stadt Frankenberg, Sachsen; 5 - Hohenforst, Gemeinde Kirchberg, Sachsen.

osadami a hornickými sídlišti pozorujeme v uspořádání intravilánů. U hornických osad nenalezneme žádný ze známých půdorysných typů agrárních sídel. Jsou často extenzivní a rozptýlené. Častým prvkem je opevněný bod v podobě tvrze, čímž se ale hornická sídliště od mnohých zemědělských osad kategoricky neliší. Hornická sídliště se na rozdíl od zaniklých zemědělských osad nijak neprojevují v historické plužině jako její integrální, či dokonce generující prvek. Zároveň se v plužině neprojevují ani jako rušivý prvek, jako je tomu u samotných pozůstatků důlních pracovišt', jejichž rekultivace po opuštění nebyla snadná. Preferovaný výběr území je jiný než u osad zemědělských a plyne ze specifického účelu těchto sídel i z báňskoprávních zásad, které byly ještě ve 13. století kodifikovány. Osady horníků a hutníků jsou co nejblíže důlním, rýžovnickým, úpravnickým a hutnickým pracovištím.

Z písemných pramenů 13. a 14. století vyplývají zásady, podle nichž by snad bylo možné hledat $\mathrm{v}$ uspořádání staveb $\mathrm{v}$ hornických osadách určitý řád. Na každou nově vyměřenou sedmilánovou důlní míru připadá podle jihlavského privilegia ve znění listiny A celkem 16 parcel (Item quilibet mons mensuratus XVI areas de jure obtinebit), přičemž užitý výraz area lze chápat jako označení pro parcelu, na níž má stát obydlí (CIB I, 116). Z německy formulovaného právního naučení z druhé poloviny 14 . století sestaveného v Jihlavě vyplývá, že na takto chápaných 16 parcelách (Hofsteten) mají být obydlí u dolu postavena řádně (die schollen ordenleich gepauet sein pei der zeche; Tomaschek 1897, 46-47 č. 86, obdobně 66 č. 93). Několik listin z let 1258-1351 obsahuje také dílčí údaje o infrastruktuře nejrozvinutějších důlních osad na Havlíčkobrodsku, na centrální Českomoravské vrchovině. Na třech z nich evidujeme kostel či kapli. Prvním je Mittelberg (Medio monte), jehož existence je poprvé doložena listinou olomouckého biskupa Bruna z 20. října 1256 (CDB V/1, 164 č. 90; Rous 2001, 67-69, 76; 2004, 50-51). Dalším je centrum při ústí Borovského potoka do Sázavy, kde dodnes stojí hřbitovní kostel sv. Kateřiny. Lokalita je podle listiny z 13. června 1265 ztotožňována s důlním podnikem Herliwinberg. 


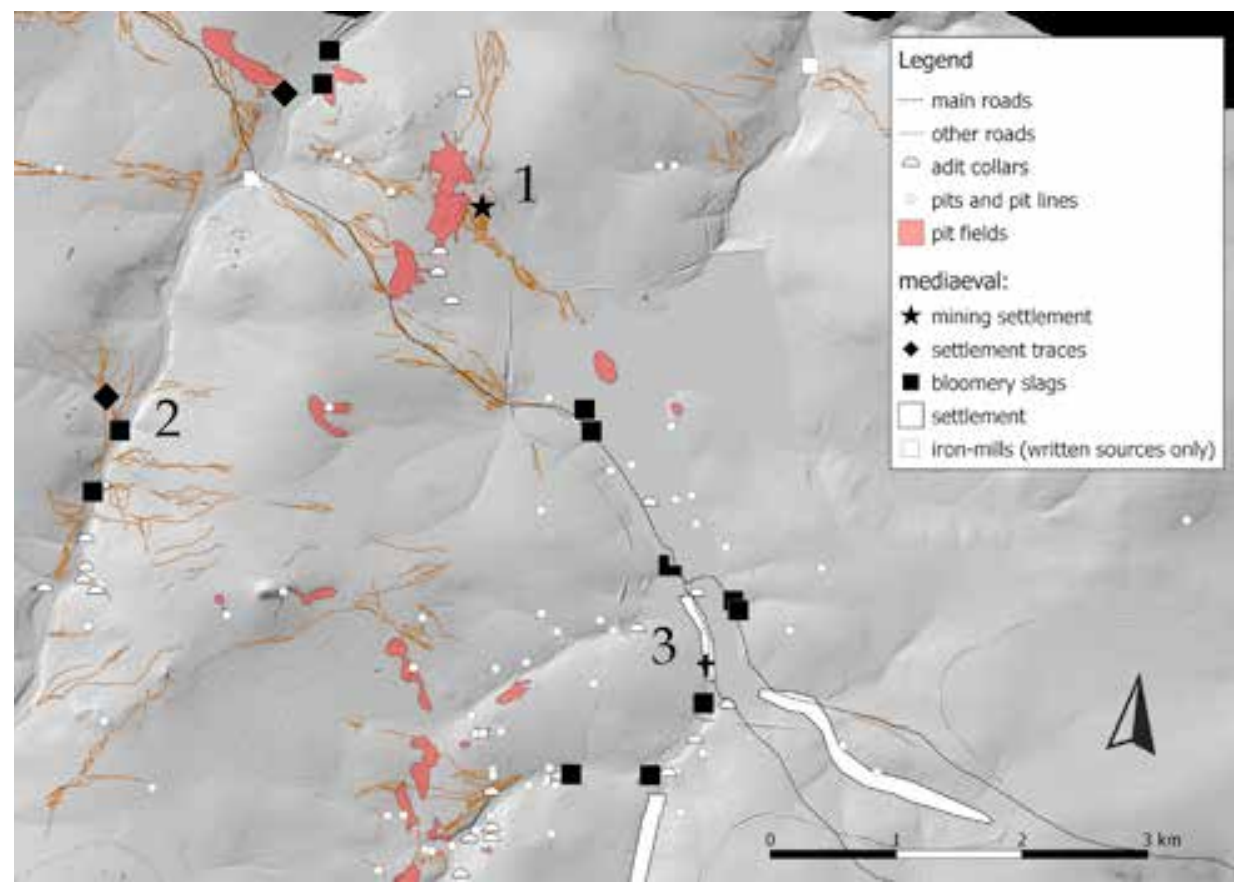

Obr. 4. Přísečnicko v Krušných horách s rekonstrukcí středověké sídlištní, výrobní, zemědělské a dopravní infrastruktury. 1 - Kremsiger, 2 - Starý Zámek, 3 - město Př́ísečnice. Průzkumy ÚAPP SZČ, úprava K. Derner.

Abb. 4. Region Př́́sečnice/Preßnitz im Erzgebirge mit rekonstruierter mittelalterlicher Siedlungs-, Produktions-, Agrarund Verkehrsinfrastruktur. 1 - Kremsiger, 2 - Starý Zámek, 3 - Stadt Pressnitz. Untersuchungen Institut für archäologische Denkmalpflege Nordwestböhmens, bearbeitet von K. Derner.

Kostel je zde zmiňován již v uvedeném roce (ecclesiam in monte Herliwini), naposledy pak ještě roku 1327. Konečně v listině z 13. června 1265 nalezneme také zmínky o kapli v dalším z důlních stř̌edisek, kterým byl Buchberg (capella in Buchberch), nynější lokalita Poperek nedaleko obce Utín (CDB V/1, 661-662 č. 447; Rous 1998, 108; 2001, 69, 71, 77; 2004, 50).

V širokém spektru uspořádání hornických sídlišt' nenalezneme jednotný vzorec. Snahu o centrální, či dokonce ortogonální půdorys lze v mladší fázi existence tušit u střediska Fürstenberg v lesní trati Hohenforst u Kirchbergu v saských Krušných horách. Ani další saské hornické sídliště na návrší Treppenhauer nevzniklo shlukem domků u jednotlivých dolů, nýbrž vykazuje ulicové uspořádání ve dvou řadách v ose jihozápad-severovýchod prŕčně na průběh rudních žil (Schwabenicky 2009, 22, Abb. 18, 191-192). Náznak ortogonálního uspořádání a konstantní šíře parcel byly nedávno prokázány na Kremsigeru v českých Krušných horách (Derner 2017; obr. 4, 9-10).

Dalším půdorysným typem je jednoduché řazení staveb souběžně s důlními jámami. To lze pozorovat na Brandes en Oisans ve francouzských Alpách. Problematické asi bylo zř́zení obydlí na lokalitě Birkenberg v Möhlintalu v jižním Schwarzwaldu. I zde pozorujeme snahu o umístění staveb podél důlních pracovišt', avšak př́íkrý svah nutil stavitele často k improvizaci, a tak stavby stojí na umělých plateau, vzniklých navršením hlušiny i zářezem (Steuer-Goldenberg 2002, 413). Podobnou situaci můžeme pozorovat na lokalitě Havírna u Štěpánova nad Svratkou v oblasti Svratecké klenby (Doležel-Sadílek 2004). Na centrální Českomoravské vrchovině řadíme do skupiny osad s liniovým uspořádáním staveb rovnoběžně s důlními pracemi hornické sídliště u Vyskytné na Pelhřimovsku i část důlního centra Poperek/Buchberg u Utína (obr. 7 


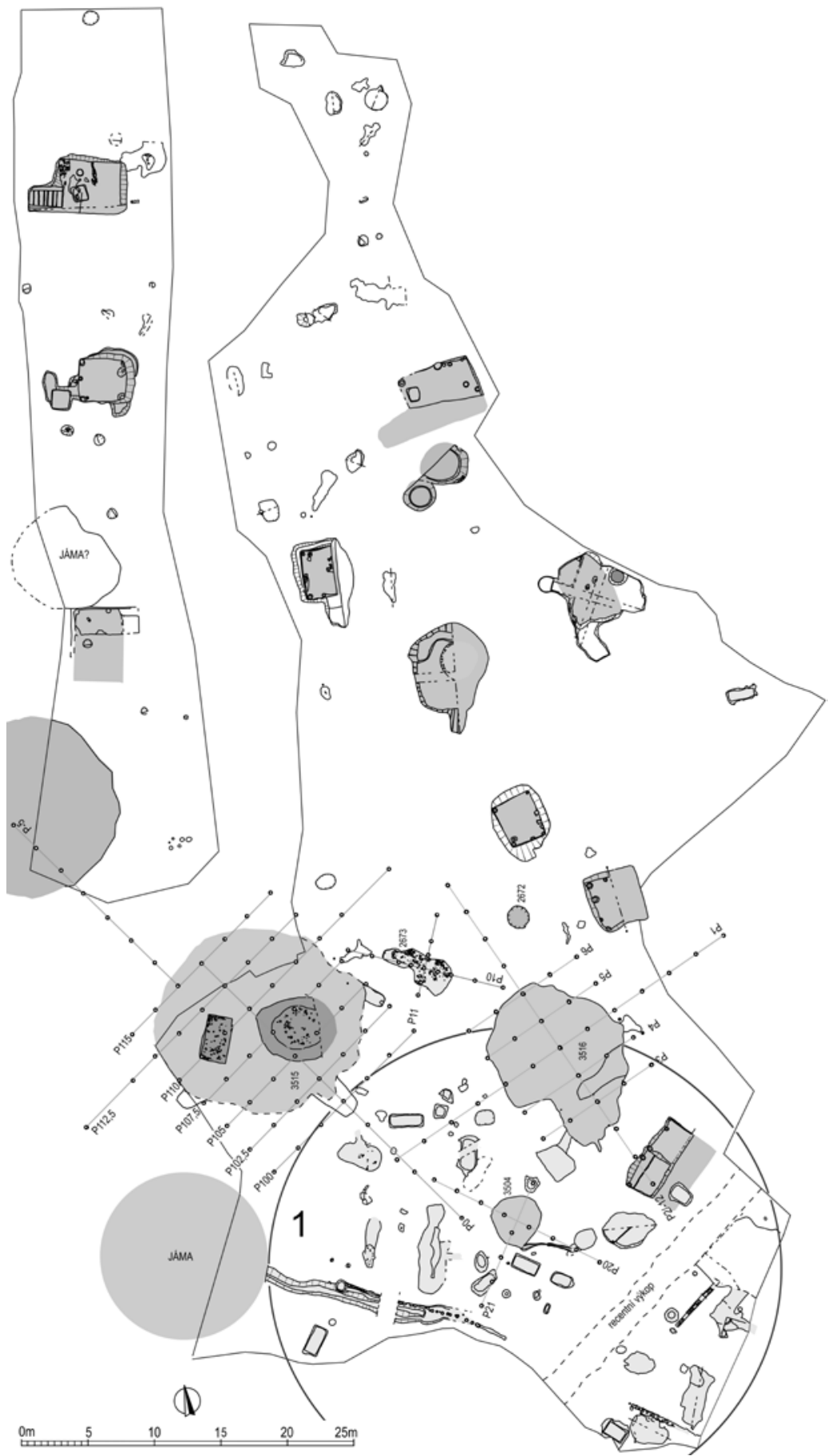

Obr. 5. Uspořádání části sídlištních areálů v důlním centru Jihlava - Staré Hory na Českomoravské vrchovině. Výzkumy Archaia Brno, o.p.s., úprava P. Hrubý.

Abb. 5. Anordnung eines Teils der Siedlungsareale im Grubenzentrum Jihlava - Staré Hory auf der Böhmisch-Mährischen Höhe. Grabungen Archaia Brno, o.p.s., bearbeitet von P. Hrubý. 


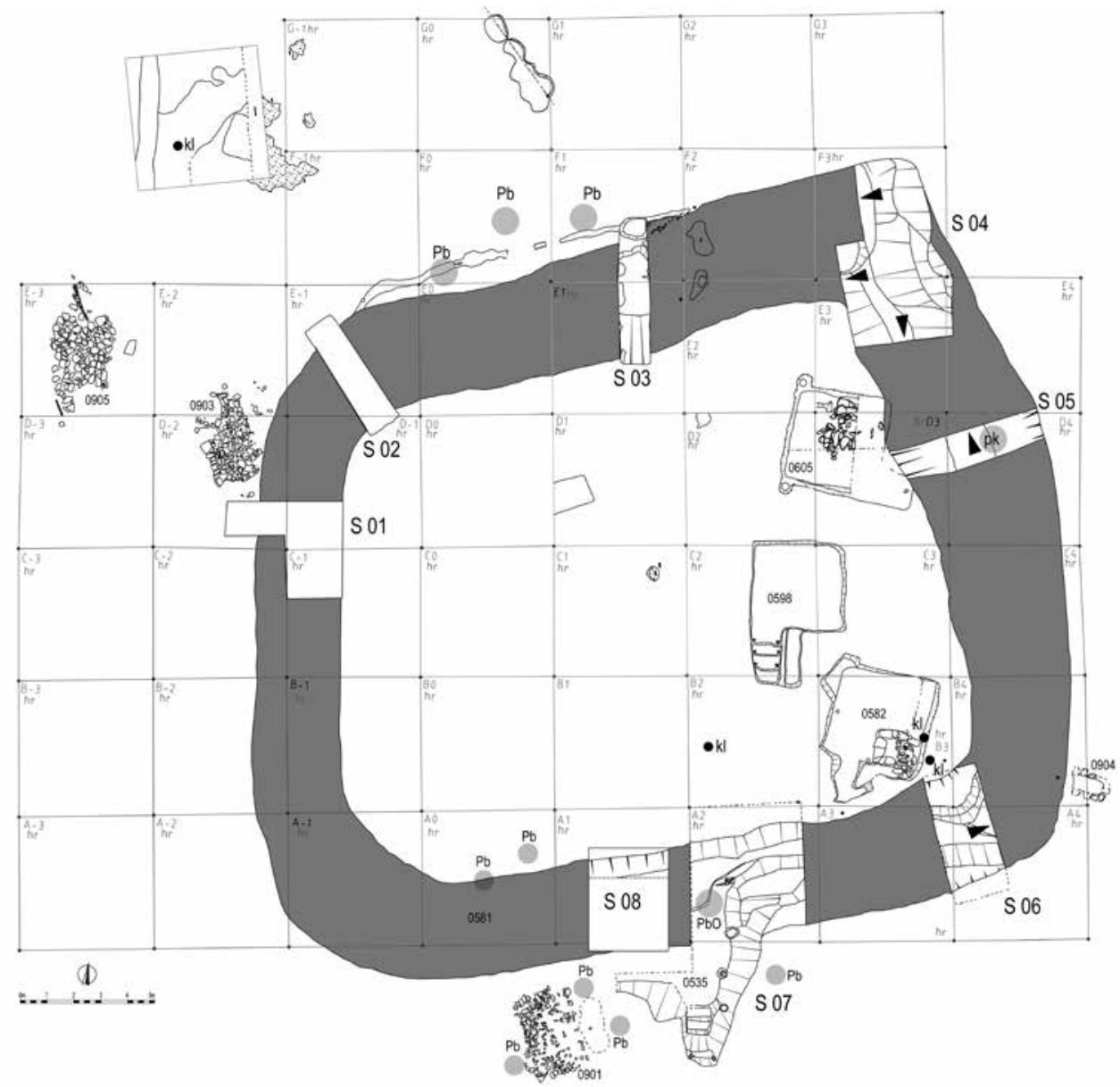

Obr. 6. Uspořádání sídlištního areálu Cvilínek, obec Chrástov, okr. Pelhřimov, na Českomoravské vrchovině. S 01-07 sondy, Pb - nálezy olověných předmětủ, kl - kladívka. Výzkum Archaia Brno, o.p.s., a Muzeum Vysočiny Jihlava, úprava P. Hrubý.

Abb. 6. Anordnung des Siedlungsareals Cvilínek, Gemeinde Chrástov, Bezirk Pelhřimov, auf der Böhmisch-Mährischen Höhe. S 01-07 - Sondierschnitte, Pb - Funde von Bleigegenständen, kl - Hämmer. Grabung Archaia Brno, o.p. s., und Museum der Böhmisch-Mährischen Höhe Jihlava, bearbeitet von P. Hrubý.

a 8). Na lokalitě Cvilínek u Černova na Pelhřimovsku bylo uskupení hornických obydlí několik a podobně jako u jihlavských Starých Hor, Vyskytné či lokality Buchberg nebylo zdejší sídliště soustředěno na jediné místo (obr. 5 a 6 ).

Na konci spektra se nachází areály, $v$ nichž jsou stavby a obydlí neuspořádané a shlukové. To je př́iklad střediska Altenberg v německé hornatině Siegerland v Severním Porýní-Vestfálsku, kde časté sousedství staveb a šachet vedlo k úvaze o souvislosti s formou držby dolů, v tomto případě lénhaviŕrskou, kdy provozovatelé dolů pracují nájemně na dolech prvotních držitelů propůjček (Lobbedey 1998, 38, Abb. 5). Tomuto půdorysnému obrazu se ze sídlišt' centrální Českomoravské vrchoviny blíží nejvíce jihlavské Staré Hory. 


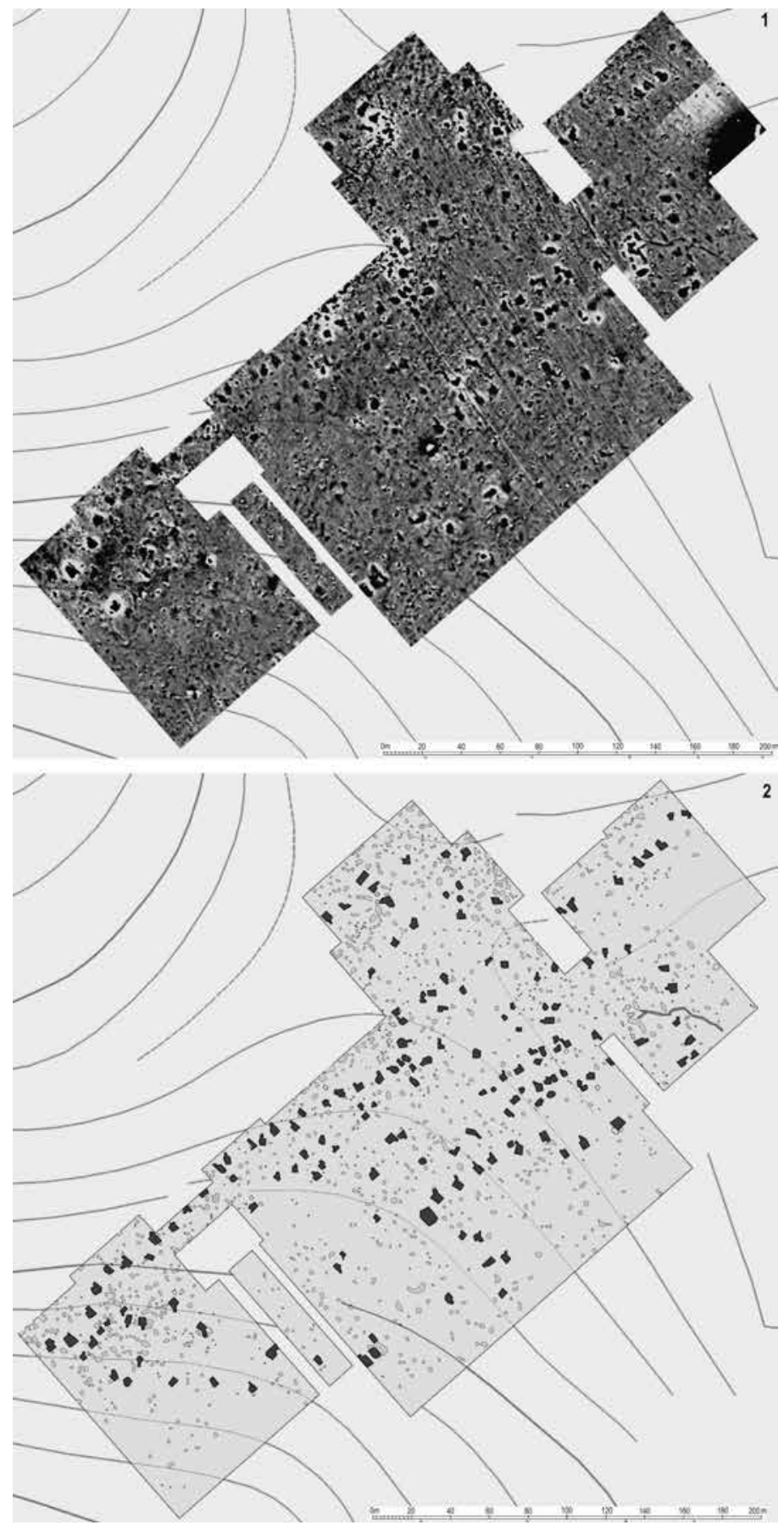

Obr. 7. Uspořádání sídlištního areálu u Vyskytné, okr. Pelhřimov, na Českomoravské vrchovině. Průzkumy Archaia Brno, o.p.s., a ÚAM FF MU Brno, geomagnetika P. Milo, úprava P. Hrubý.

Abb. 7. Anordnung des Siedlungsareals bei Vyskytná, Bezirk Pelhřimov, auf der Böhmisch-Mährischen Höhe. Untersuchungen Archaia Brno, o. p. s., und Institut für Archäologie und Museologie der Philosophischen Fakultät der Masaryk-Universität Brno, Geomagnetik P. Milo, bearbeitet von P. Hrubý. 

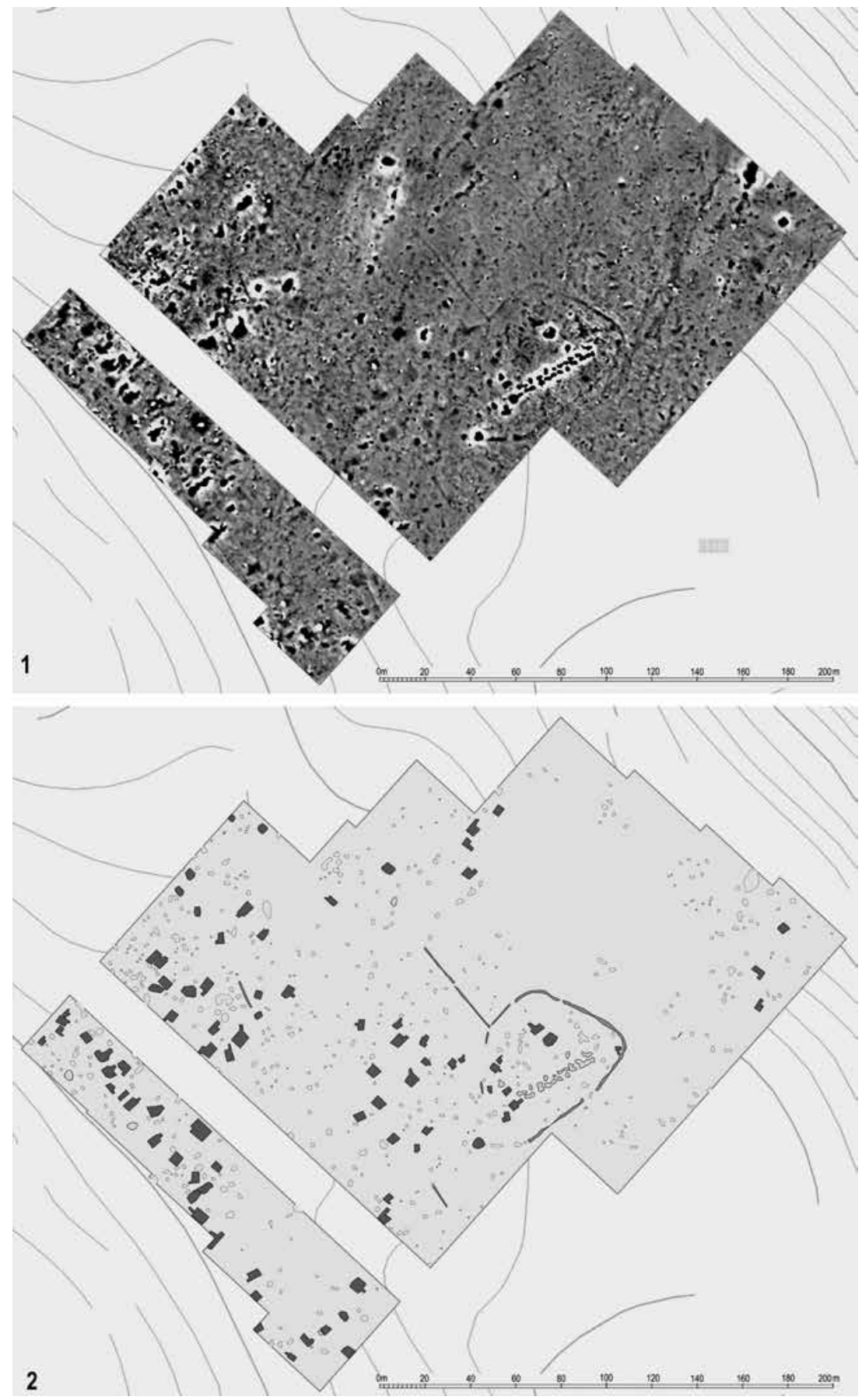

Obr. 8. Uspořádání sídlištního areálu u Utína, okr. Havlíčkův Brod, na Českomoravské vrchovině. Průzkumy Archaia Brno, o.p.s., a ÚAM FF MU Brno, geomagnetika P. Milo, úprava P. Hrubý.

Abb. 8. Anordnung des Siedlungsareals bei Utín, Bezirk Havličkủv Brod, Institut für Archäologie und Museologie der Philosophischen Fakultät der Masaryk-Universität Brno. Untersuchungen Archaia Brno, o. p. s., und Institut für Archäologie und Museologie der Philosophischen Fakultät der Masaryk-Universität Brno, Geomagnetik P. Milo, bearbeitet von P. Hrubý. 


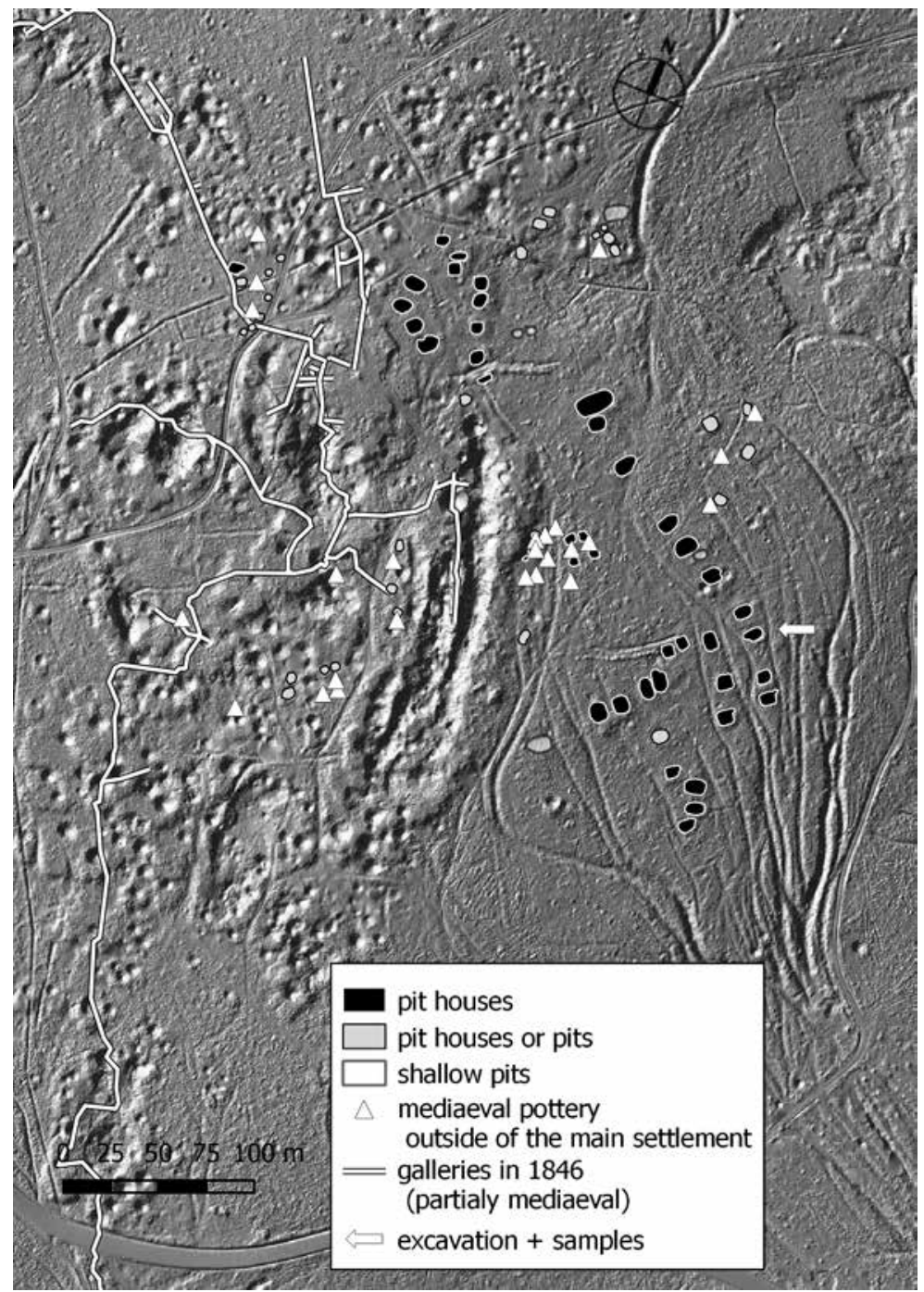

Obr. 9. Celkový plán zaniklé stř̌edověké lokality Kremsiger v Krušných horách s hypotetickým rozlišením sídlištního areálu. Výzkum ÚAPP SZČ, úprava K. Derner.

Abb. 9. Gesamtplan der untergegangenen mittelalterlichen Fundstelle Kremsiger im Erzgebirge mit hypothetischer Unterscheidung der Siedlungsareale. Grabung Institut für archäologische Denkmalpflege, bearbeitet von K. Derner.

\subsection{Podoba obydlí a absence dokladi̊ hospodářské i sanitární infrastruktury}

Nejčastějšími nalézanými pozůstatky staveb na hornických sídlištích jsou zahloubené struktury (obr. 11-15). Nepochybně hrály roli v procesech zpracování suroviny a v metalurgických činnostech, sloužily jako sklady, podstatná je ale jejich funkce obytná. Typy staveb na hornických sídlištích jsou už z podstaty věci specifické a nedá se říci, že jednoznačně odpovídají soudobému stavitelství městskému nebo vesnickému. V hornických osadách téměř nenalézáme pozůstatky vícedílných domů, hospodářských staveb a dvorcového uspořádání usedlostí. Také 


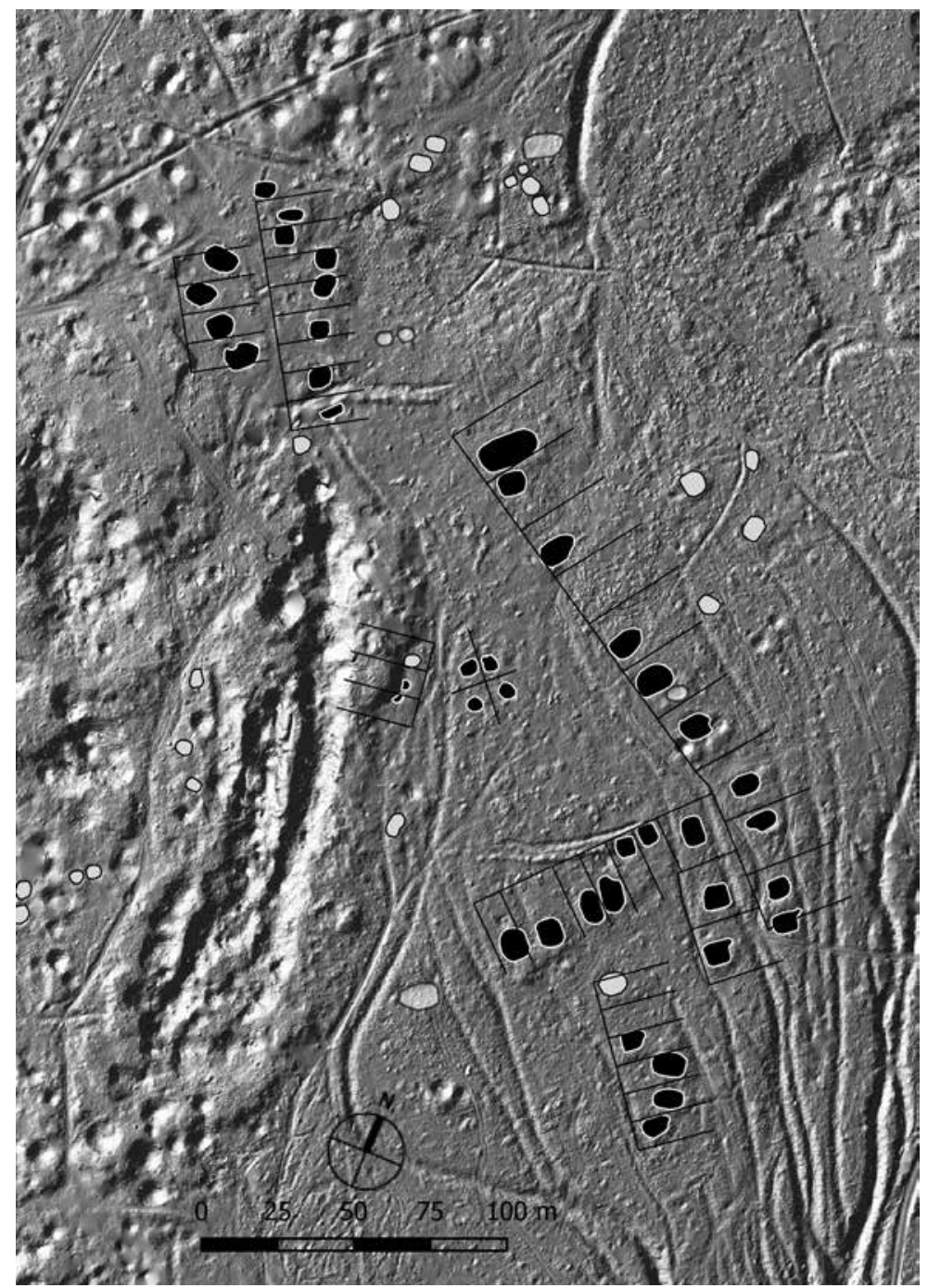

Obr. 10. Lokalita Kremsiger v Krušných horách s hypotetickou rekonstrukcí parcelace v rámci sídlištního areálu. Výzkum ÚAPP SZČ, úprava K. Derner.

Abb. 10. Fundstelle Kremsiger im Erzgebirge mit hypothetischer Rekonstruktion der Parzellierung im Rahmen des Siedlungsareals. Grabung Institut für archäologische Denkmalpflege, bearbeitet von K. Derner.

zde až na výjimky (odpadní jáma a studna na lokalitě Treppenhauer - Schwabenicky 2009, 243) nenalézáme sanitární infrastrukturu. Např́iklad v jihlavských Starých Horách chybí přes rozsah odkryvů přesvědčivé doklady odpadních jam, jímek, studní apod. V otázce zdrojů pitné vody lze vzhledem ke specifikům důlní a úpravnické činnosti předpokládat, že zdejší vodoteče tuto funkci plnit nemohly kvůli všestrannému znečištění. $V$ úvahu tak připadá přívod pitné vody nadzemními dřevěnými vodovody, zakončenými dřevěnými kašničkami a napajedly, podobně jako tomu dodnes ještě může být u některých tradičních horských vsí či menších městeček naprríklad v alpském či karpatském prostředí. 


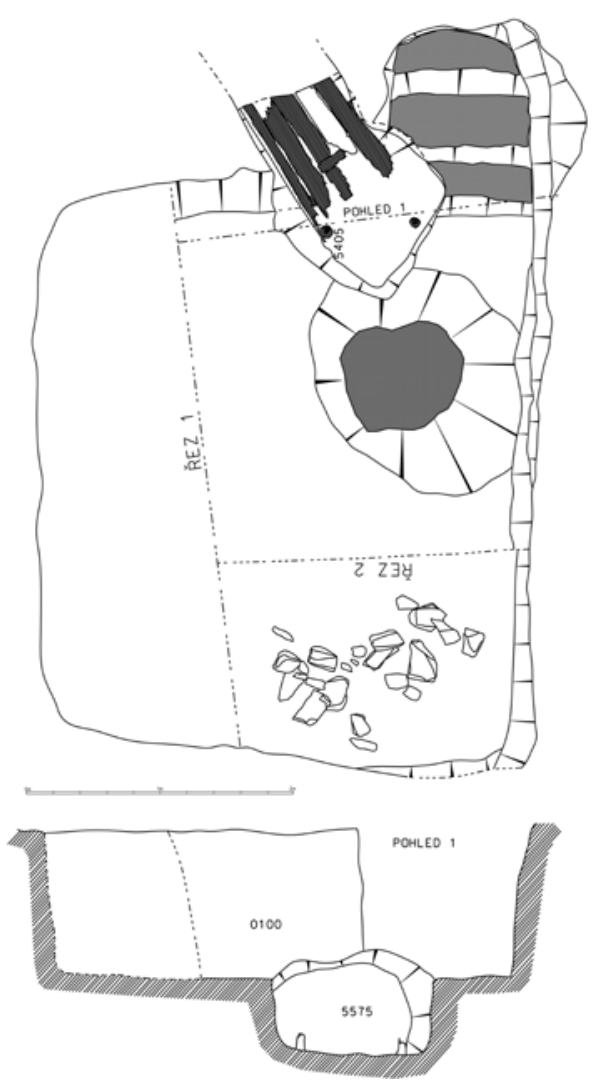

Obr. 11. Zahloubené stavby se zásobními prostory v důlním středisku Jihlava - Staré Hory na Českomoravské vrchovině. Výzkumy Archaia Brno, o.p.s., úprava P. Hrubý. Abb. 11. Eingetiefte Bauten mit Vorratsräumen im Grubenzentrum Jihlava - Staré Hory auf der Böhmisch-Mährischen Höhe. Grabungen Archaia Brno, o.p.s., bearbeitet von P. Hrubý.

\section{Prameny k zemědělství a potravinářství hornických osad}

\subsection{Zásobování, potravinářství a zemědělství hornických center $v$ písemných pramenech}

Třinácté století je z hlediska etablování hornických komunit $\mathrm{v}$ přemyslovském prostředí přelomovým a kontrastním obdobím. Počátky hornictví u nás spadají do třicátých až čtyřicátých let a jsou poznamenány teprve zakládáním měst, dobudováváním zemědělské sídelní infrastruktury, rozvojem trhu a složitým utvářením pracovně právních i organizačních vztahů v produkci kovů. Konec 13. a počátek 14. století skýtá naproti tomu obraz již etablovaných měst s patricijskou elitou, podnikající v řemesle, obchodu, peněžnictví a pochopitelně také $\mathrm{v}$ hornictví. Samozřejmostí jsou v tomto směru konsorcia nejbohatších podnikatelů, kteří kontrolují nejvýnosnější rudní ložiska a kteří si mezi sebou dělí výnosné úřady mincmistrů a urburéřů (Jan 2006, 79-160). Vybroušená kodifikovaná znění báňských zákoníků téměř dokonale postihují každodenní praxi dolů a hutí.

Některé informace o zásobování mohou prozradit zásady zřizování a regulace hornických sídlišt' obsažené $\mathrm{v}$ právních dokumentech pokročilého 13 . a 14. století. $\mathrm{Na}$ každé důlní míře mohlo být zřízeno 16 obydlí, přičemž v jednom, dvou či ve více takových staveních mohlo být zř́zeno řeznictví, pekařství a lázně. Mohlo se zde také šenkovat pivo, medovina a víno (CIB I, 116, 329; Tomaschek

1897, 46-47 č. 84 a 86). Konkrétním příkladem existence takového šenku je důlní centrum Buchberg v trati Poperek východně od obce Utín na Havlíčkobrodsku. Ten je poprvé zmiňován v propůjčce z 25. října 1258 (CDB V/1, 269 č. 168). O rozvinuté infrastruktuře i dobrém zásobování střediska v druhé polovině 13. století vypovídá v listině z 13 . června 1265 údaj o tzv. hospitiu (CDB V/1, 661-662 č. 447). Jeho přítomnost může být dokladem naplňování výsad, o nichž čteme ve výše zmíněném právním naučení. Jiné zmínky, z nichž lze okrajově vyvozovat představy o zásobování dolů potravinami, se dočítáme také v Ius regale montanorum (IRM), které vzniká okolo roku 1300 a které tedy odráží praxi 13. století. V první knize, kapitole VIII De magistris montium, $\S 16$ a 17, se mezi povinnostmi hormistrů uvádí, že mají dbát na to, aby se mzdy dělníkům vyplácely v penězích, a to tak, aby ti chudí nečelili nedostatku jídla. Taktéž mají dbát na dostatečné zásobování dělníků jídlem, aby se předcházelo krádežím (CIB I, 294, 295). V kapitole III Druhé knihy IRM se můžeme ve výčtu horních svobod dočíst mimo jiné o volnosti použíání dřeva z lesů a hájů dotčených pozemkových vlastníků. Ze své činnosti ani z těžby dřeva mu nemusí horníci platit. Zajímavý je i údaj, že k obydlím si horníci smějí na dostřel luku od dolu (okolo $300 \mathrm{~m}$ ) zrrídit i pastviny pro svůj dobytek (CIB I, 328). 

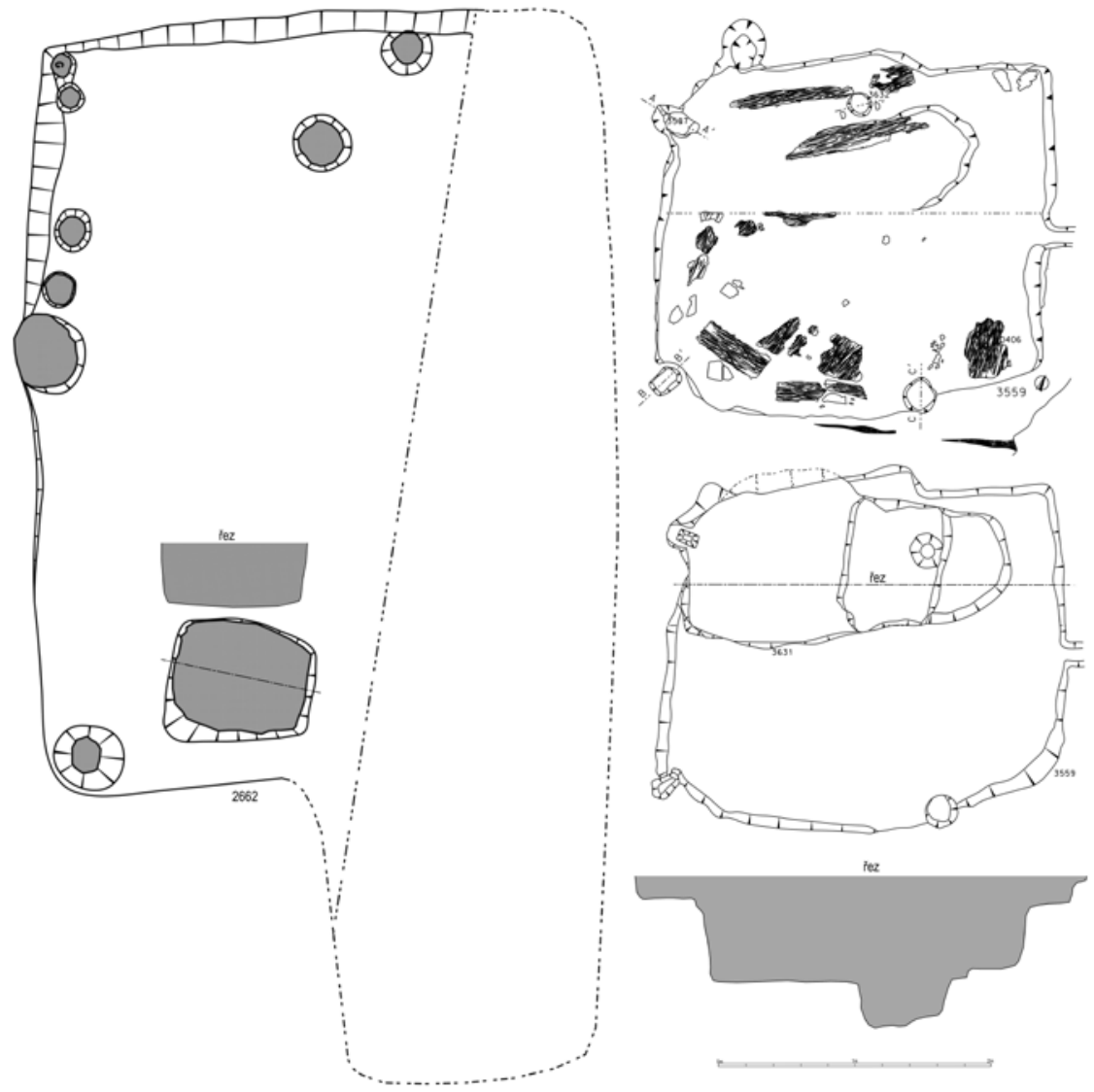

Obr. 12. Zahloubené stavby se zásobními prostory v důlním středisku Jihlava - Staré Hory na Českomoravské vrchovině. Výzkumy Archaia Brno, o.p.s., úprava P. Hrubý.

Abb. 12. Eingetiefte Bauten mit Vorratsräumen im Grubenzentrum Jihlava - Staré Hory auf der Böhmisch-Mährischen Höhe. Výzkumy Archaia Brno, o.p.s., bearbeitet von P. Hrubý.

\subsection{Otázka skladování a tepelného zpracování potravin varcheologickém obrazu hornických osad}

\section{Zahloubené sklípky}

V hornických osadách se jen zřídka setkáme se zásobními jámami. Specifikem staveb v jihlavských Starých Horách jsou hloubené sklípky v interiérech suterénních i nezahloubených pozůstatků dřevohliněných staveb. Jeden takový byl v suterénní části jedné ze staveb umístěn vpravo od vstupní šíje, jeho dno mělo ještě zbytky výdřev. Jinou variantu představuje jednoduchý podpodlažní jámový sklípek (obr. 11-12). Podobné prostory, navázané na interiéry zemnic, známe z lokality Sekanka na Hradišt'ku u Davle (Richter 1982, 29, 30, 44, dále T 13:2, T 15:1).

\section{Absence zásobnic v keramice}

V hmotné kultuře je odchylkou od souborů středověké keramiky jednoznačně nápadně malé až nulové zastoupení zásobnic (Waldhauser a kol. 1993, 397-399; Doležel-Sadílek 2004; 58-65; Schwabenicky 2009, 91-140; Hrubý 2011, 195-221; Hrubý a kol. 2012, 385-392; Zimola 
2012, 34-42). V jihlavských Starých Horách nalézáme zásobnice z tuhové keramiky jako jednotlivosti (obr. 16).

\section{Pece v interiérech staveb}

Pozůstatky pecí v zemnicích představují interpretační problém. Především jsou vzácným jevem, takže nebyly standardním vybavením. Diskutabilní je ostatně už samotný obytný charakter zemnic, at' už se v nich pece nacházely či nikoliv. $V$ jednom jediném př́ípadě zahloubené stavby na lokalitě Staré Hory u Jihlavy byla nalezena pícka oválného až hruškovitého tvaru se zbytky kamenné konstrukce. Byla situována $\mathrm{v}$ rohu v úrovni podlahy, přičemž $\mathrm{v}$ předpokládaném manipulačním prostoru před píckou se nacházelo hladké a vypálené místo (obr. 13). Odlišný typ zařízení byl objeven při archeologickém výzkumu hornického sídliště Cvilínek. V rohu jedné ze zemnic se vedle vstupní šíje nacházela pec z kamene spojovaného hlínou. Měla obdélný půdorys o rozměru $1,5 \times 1,3 \mathrm{~m}$. Vrchní část pece nebyla zachována, nicméně lze předpokládat valené zaklenutí (obr. 14). Dvě takové pece v důlním středisku Treppenhauer jou interpretovány jako vytápění lázně, poněvadž zabírají značnou plochu nápadně malých interiérů (Schwabenicky 2009, 72-77).

\section{Ohniště v interiérech zahloubených staveb}

Jako častější se v zemnicích jeví archeologicky málo čitelné stopy ohništ', či jen kumulace uhlíků, zašlapaných do podlahové vrstvy. Na některých hornických sídlištích však přes reprezentativní stav výzkumu postrádáme i ty nejmenší doklady topeništ' (Derner 2017, 52, 55-56, 62-65, 149-152). U jednoduchých ohništ' v interiérech zemnic snad lze uvažovat o ohřívání pokrmů, vaření, rožnění či smažení, nikoliv ale o pečení chleba. Příkladem je nález hrnců okolo jednoduchého ohniště v zemnici na lokalitě Sekanka na Hradišt'ku u Davle (Richter 1982, 43-44, T 17:2 a 3, T 21:3). Jednoduché ohniště se nejspíš nacházelo i v zahloubené stavbě na

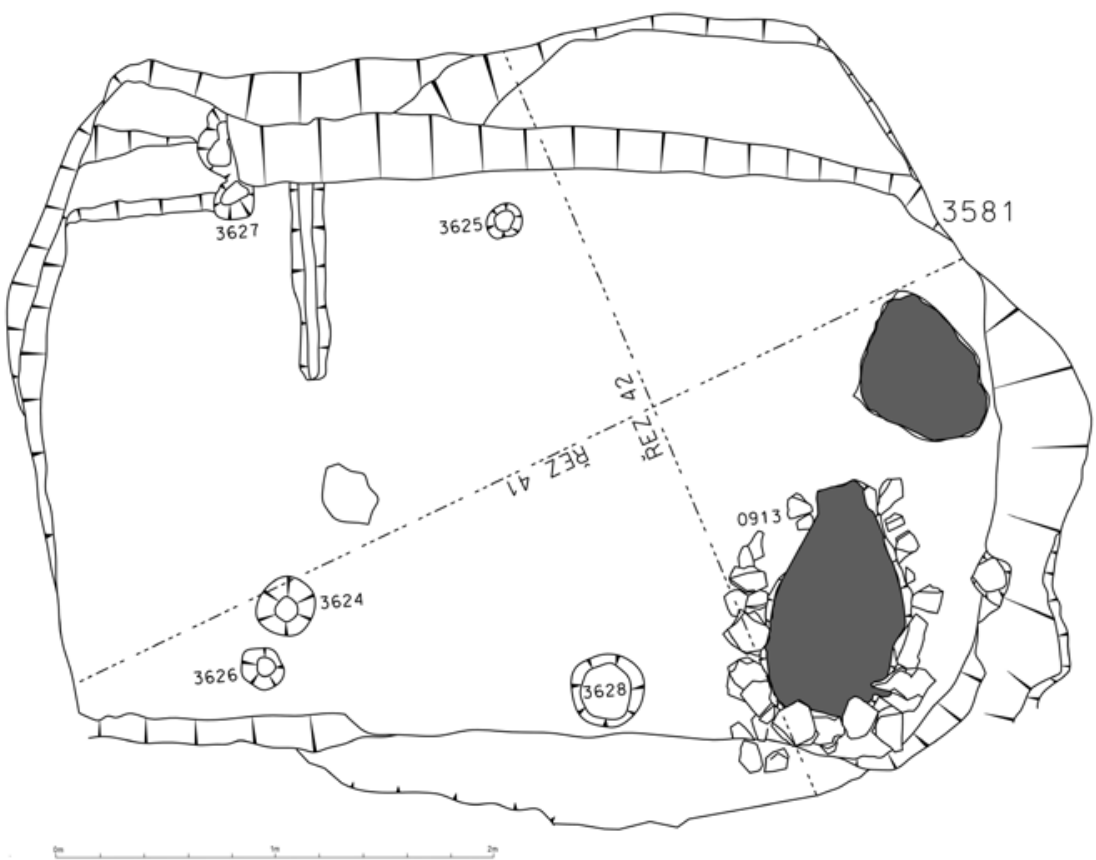

Obr. 13. Zahloubené stavby s pozůstatky pece v důlním středisku Jihlava - Staré Hory na Českomoravské vrchovině. Výzkumy Archaia Brno, o.p.s., úprava P. Hrubý.

Abb. 13. Eingetiefte Bauten mit Ofenrelikten im Grubenzentrum Jihlava - Staré Hory auf der Böhmisch-Mährischen Höhe. Grabungen Archaia Brno, o.p.s., bearbeitet von P. Hrubý. 


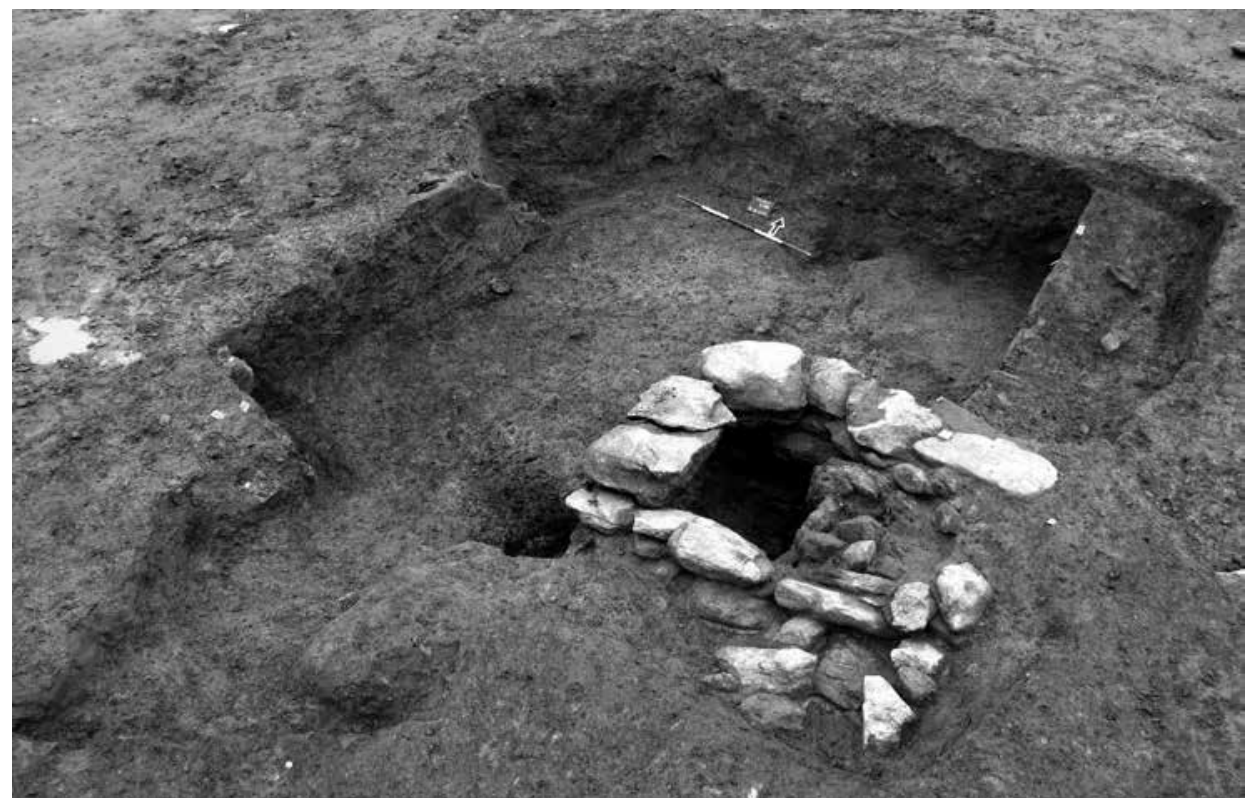

Obr. 14. Zahloubené stavby s pozůstatky pece na lokalitě Cvilínek na Českomoravské vrchovině. Výzkumy Archaia Brno, o. p.s., úprava P. Hrubý.

Abb. 14. Eingetiefte Bauten mit Ofenrelikten an der Fundstelle Cvilínek auf der Böhmisch-Mährischen Höhe. Grabungen Archaia Brno, o.p.s., bearbeitet von P. Hrubý.

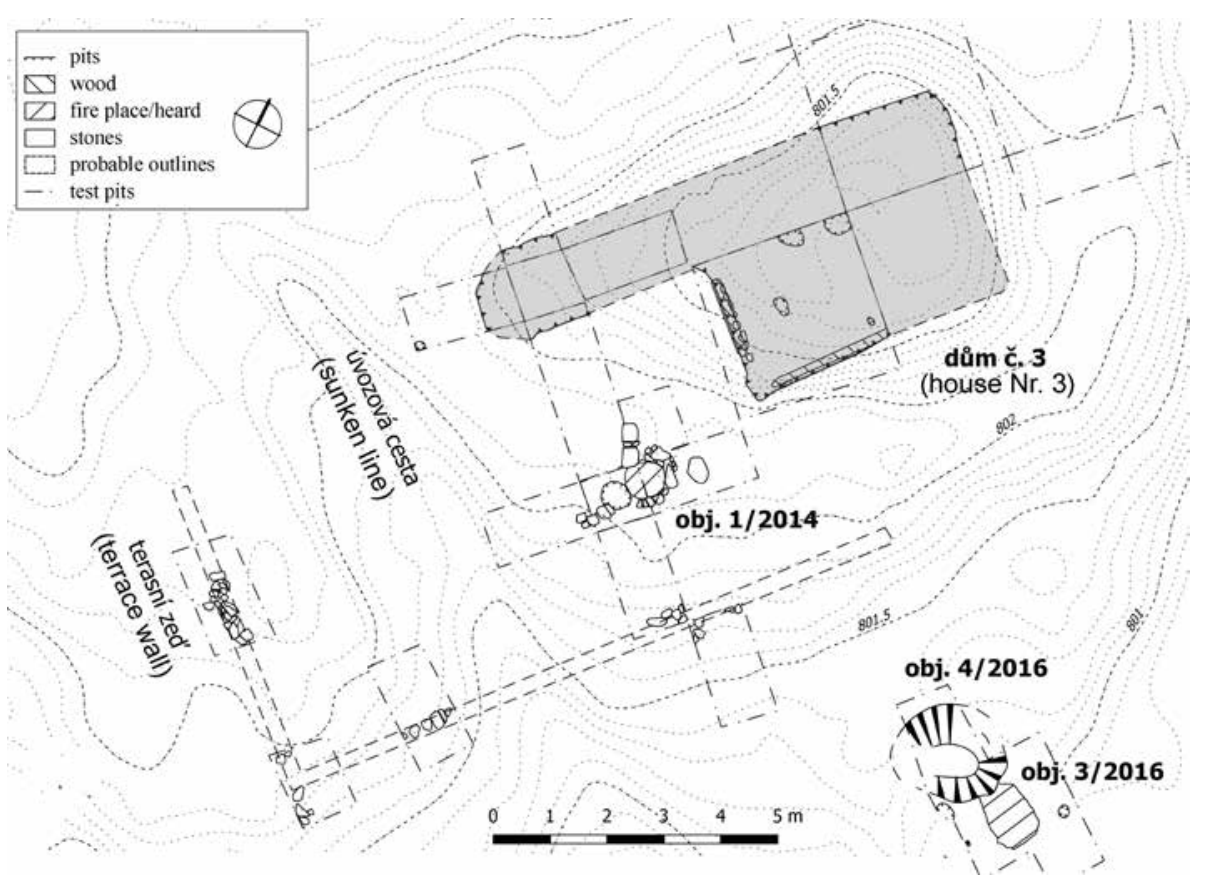

Obr. 15. Zahloubená stavba s blízkou pecí v úrovni povrchu na lokalitě Kremsiger v Krušných horách. Výzkum ÚAPP SZČ, úprava $\mathrm{K}$. Derner.

Abb. 15. Eingetiefter Bau mit nahegelegenem Ofen auf Oberflächenniveau an der Fundstelle Kremsiger im Erzgebirge. Grabung Institut für archäologische Denkmalpflege, bearbeitet von K. Derner. 
hornickém sídlišti Kremsiger. Souvislost této nálezové situace s př́pravou pokrmů by mohla vyplývat z nálezu zuhelnatělé obilky žita, zašlapané do podlahy mezi vymetenými uhlíky (Derner 2017, 49).

\section{Pece a ohniště na úrovni terénu}

Nejvíce je takových objektů známo z výzkumu střediska Treppenhauer. Obdélné pece s kamennou kupolí a ohništěm $\mathrm{v}$ předpecí jsou srovnatelné s pecemi v zemědělských usedlostech. Schwabenicky předpokládá jejich široké využití k vytápění nadzemních obytných partií domů, při př́ležitostných metalurgických činnostech a konečně také při zpracování potravin. Exteriérová kruhová pec s kamennou kupolí o průměru $70 \mathrm{~cm}$ a mělkou předpecní jámou byla nalezena na terase před zahloubenou stavbou 3 na lokalitě Kremsiger v Krušných horách (obr. 15). I zde lze na základě jednak nálezů technogenního charakteru i výsledků geochemie a jednak velmi slabého propálení dna uvažovat o multifunkčním využití (Derner 2017, 62-64). Z hlediska tepelného režimu ,přeizolované“ zahloubené stavby by vysunutí pece do exteriéru bylo výhodné zvláště pro pečení v letních měsících (srov. Skružný 1980, 228).

\subsection{Hornické osady, obiloviny a obilnářství: výpověd’ archeologie a archeobotaniky}

O reliktech zemědělských ploch, v minulosti kultivovaných, lze s opatrností uvažovat na lokalitách Starý Zámek I a II, odkud známe roztroušené keramické zlomky ve svahu nad hutnickými areály (Crkal 2017, 46). V důlním středisku Altenberg v Severním Porýní-Vestfálsku pak byly zjištěny terasy, jež jsou pokládány za polnohospodářské (Lobbedey 1998, 28-29). V samotné hmotné kultuře kromě srpů z lokalit Kremsiger a Starý Zámek na české straně Krušných hor neznáme zemědělské nástroje vůbec (Derner 2017, 100; Crkal 2017, 46; obr. 17). S absencí dokladů obilnářství ve hmotných a písemných pramenech kontrastuje výpověd’ pylových záznamů na hornických sídlištích. Ve zmiňovaném středisku Altenberg bylo zachyceno 22,4\% trav, převážně žita (Isenberg 1998, 239). Na lokalitě Treppenhauer v saském Podkrušnohoří množství pylu žita $\mathrm{v}$ záznamu natrvalo klesá, a to shodně se zánikem sídliště v první polovině 14. století (Schwabenicky 2009, 162, Abb. 334). Výskyt pylů v různých hloubkách profilů ukazuje, že se jednalo o obilnářství soustavné, přičemž mohlo mít formu subsistenčního obilnářství v nejvlastnějším smyslu. Jak ukazují nové geochemické průzkumy plužin v horských oblastech, minimální opravdu obdělávaná plocha pro subsistenční hospodaření zemědělských osad mohla mít výměru snad jen 2-3 ha na usedlost (Klír 2016, 23; Horák-Klír 2017).

Archeobotanický obraz krušnohorských hornických sídlišt' doplňuje nejnověji výzkum zemnice a dalších sídlištních objektů z raného 13. století na území později konstituovaného
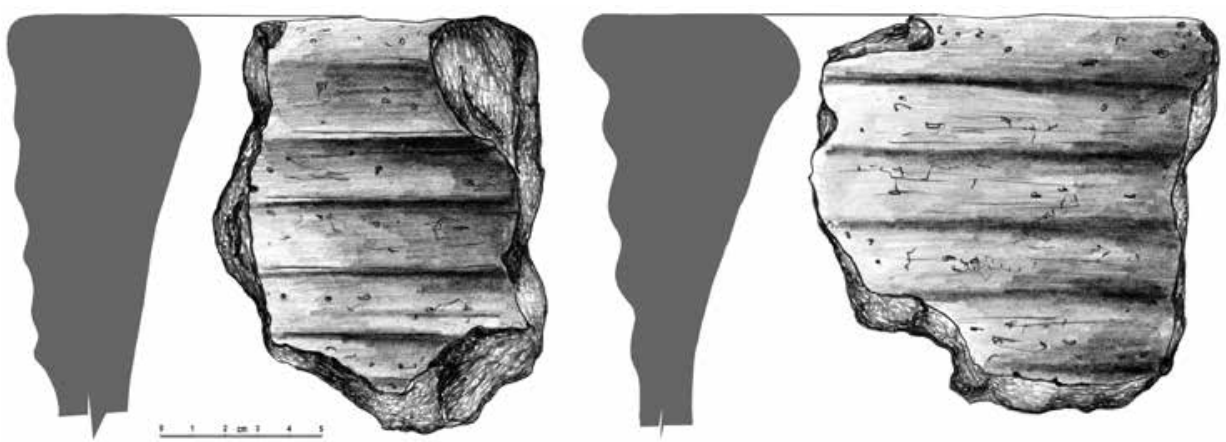

Obr. 16. Ojedinělé zlomky okrajů keramických zásobnic z hornického sídliště Jihlava - Staré Hory. Kresba E. Šamalová-Bílková, výzkum Archaia Brno, o.p.s.

Abb. 16. Verzeinzelte Randfragmente von Keramikvorratsbehältern aus der Bergbausiedlung Jihlava - Staré Hory. Zeichnung E. Šamalová-Bílková, Grabung Archaia Brno, o.p.s. 


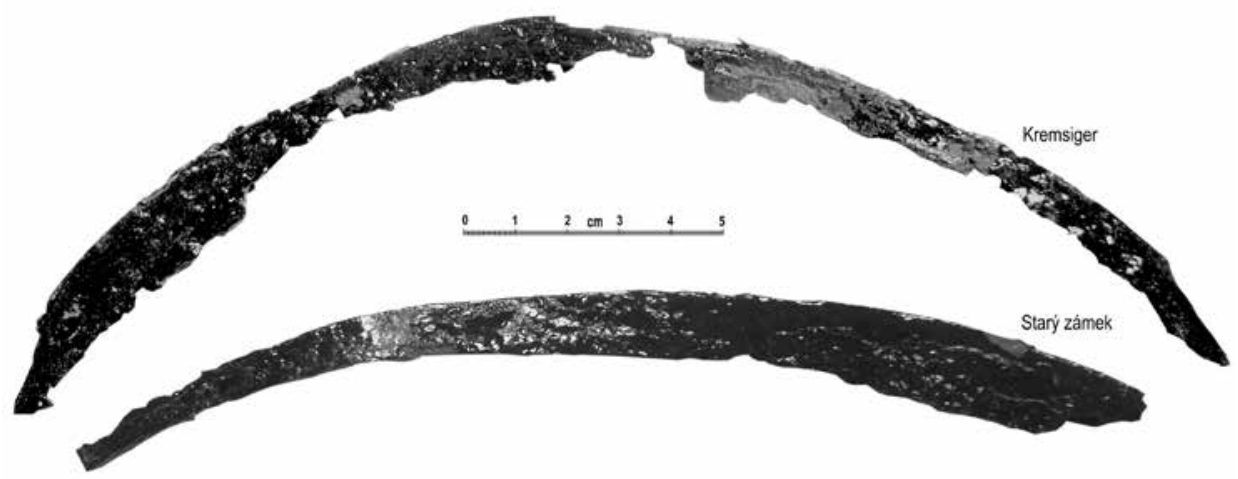

Obr. 17. Železné srpy z krušnohorských lokalit Kremsiger a Starý Zámek. Výzkum a foto ÚAPP SZČ. Abb. 17. Eisensicheln von den Erzgebirgsfundstellen Kremsiger und Starý Zámek. Grabung und Foto Institut für archäologische Denkmalpflege.

města Dippoldiswalde na saské straně horského hřebene. Osmnáct rostlinných makrozbytků pochází z průzkumné šachty a 96 ze zemnice. Bylo zjištěno široké spektrum užitných plodin, jako žito (Secale cereale), pšenice setá (Triticum aestivum) a ječmen setý (Hordeum vulgare). Žito představuje na středověkých sídlištích v Sasku nejčastější chlebovou obilninu. Běžný je i výskyt pšenice, ovšem v tomto případě je vůbec poprvé doložena na hornickém sídlišti v Sasku. Ječmen se na těchto nalezištích zatím vyskytuje zřídka. $Z$ důvodu chybějícího lepku je vhodný spíše pro kaše, jako krupice, zavářka do polévky nebo k vaření piva. Dále byl doložen celer (Apium graveolens), hrách (Pisum sativum), mák (Papaver somniferum) a len (Linum usitatissimum). Spektrum plevelů ze zemnice se téměř výlučně skládá z druhů, které jsou charakteristické pro pěstování ozimů, především žita: koukol polní (Agrostemma githago), rmen rolní (Anthemis arvensis), kopretina bílá (Chrysanthemum leucanthemum) a vikev čtyřsemenná (Vicia tetrasper$m a$ ). Kozlíček zubatý (Valerianella dentata) by mohl být i salátovou rostlinou. Úlomky kostí a zbytky ryb jako doklad živočišných potravin dotvářejí obraz vyvážené stravy horníků z obilnin, bohatých na uhlohydráty, luštěnin, obsahujících proteiny, na tuk bohatých olejnin a zeleniny (Schubert a kol. 2014, 201-202).

V makrozbytcích hornického sídliště Cvilinek u Černova na Českomoravské vrchovině v nadmořských výškách mezi $640-660$ m byly zjištěny zuhelnatělé obilky nenáročných druhů jako oves, ječmen obecný a okrajově žito či proso. Obě prvně zmíněné obilniny byly často využívány jako doplňkové jádrové krmivo koní a soumarů, jejichž uplatnění bylo v hornictví značné. Z ostatních plodin byl zaznamenán nenáročný len setý (Hrubý a kol. 2012, 403-405). Odlišný obraz skýtají jihlavské Staré Hory v centru Českomoravské vrchoviny, které byly v měřítku přemyslovského státu perspektivním a lidnatým velkoprovozem. Zejména zuhelnatělé makrozbytky dokládají procesy probíhající v době existence sídliště. Nalézáme v nich obilniny, sbírané ovocné druhy, koření a luštěniny. Obilniny představují 43,5\%, ostatní užitkové druhy 8,5\%. Zastoupeny zde byly obilky ječmene, žita setého a pšenice obecné shloučené. Zjištěn byl odpad po čištění obilí v podobě článkủ klasového vřetene pšenice a ječmene, což může naznačovat zpracování místně pěstovaných obilnin. Z luštěnin bylo nalezeno pouze jedno semeno čočky. Nález této teplomilnější plodiny podporuje představu o dovozu komodit z klimaticky příznivějších oblastí, kterou vyvolal již nález prosa setého (Hendrychová-Kočár 2007; Kočár-Kočárová 2005; 2006; Kočár-Mihályiová 2003; Kočárová- Řeřichová 2007).

Zajímavé doklady subsistenčního zemědělství i importu plodin přinesla pylová a makrozbytková analýza výplně zátočiny potoka Černá voda na hutništi Starý Zámek, ležícím v obilnářsky nevýhodné oblasti v nadmořské výšce $750 \mathrm{~m}$. V makrozbytcích pěstovaných plodin se objevilo očekávatelně žito (Secale cereale), dále len setý (Linum usitatissimum) a lnička setá 


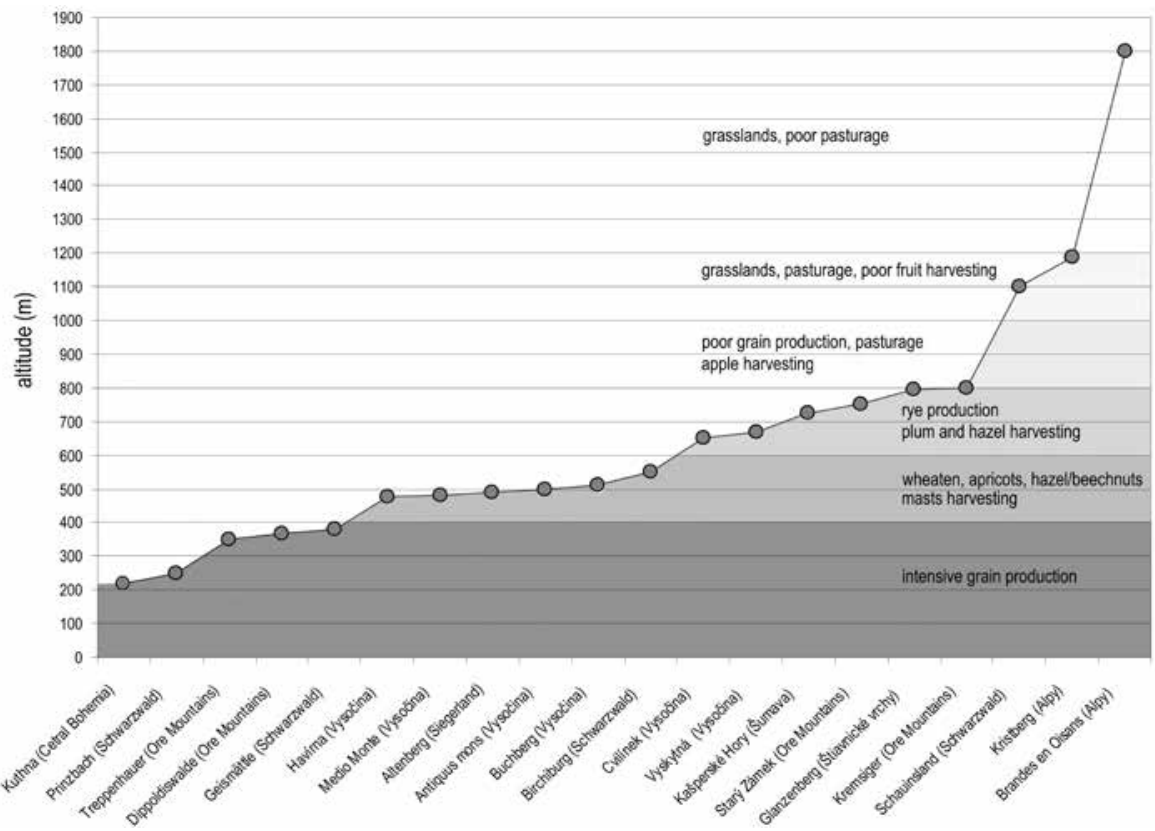

Obr. 18. Graf znázorn̆ující nadmořské výšky středověkých hornických osad v Evropě s vyznačením zón potenciální zemědělské produkce.

Abb. 18. Diagramm mit Höhendarstellung mittelalterlicher Bergbausiedlungen in Europa mit eingezeichneten potenziellen Agrarproduktionszonen.

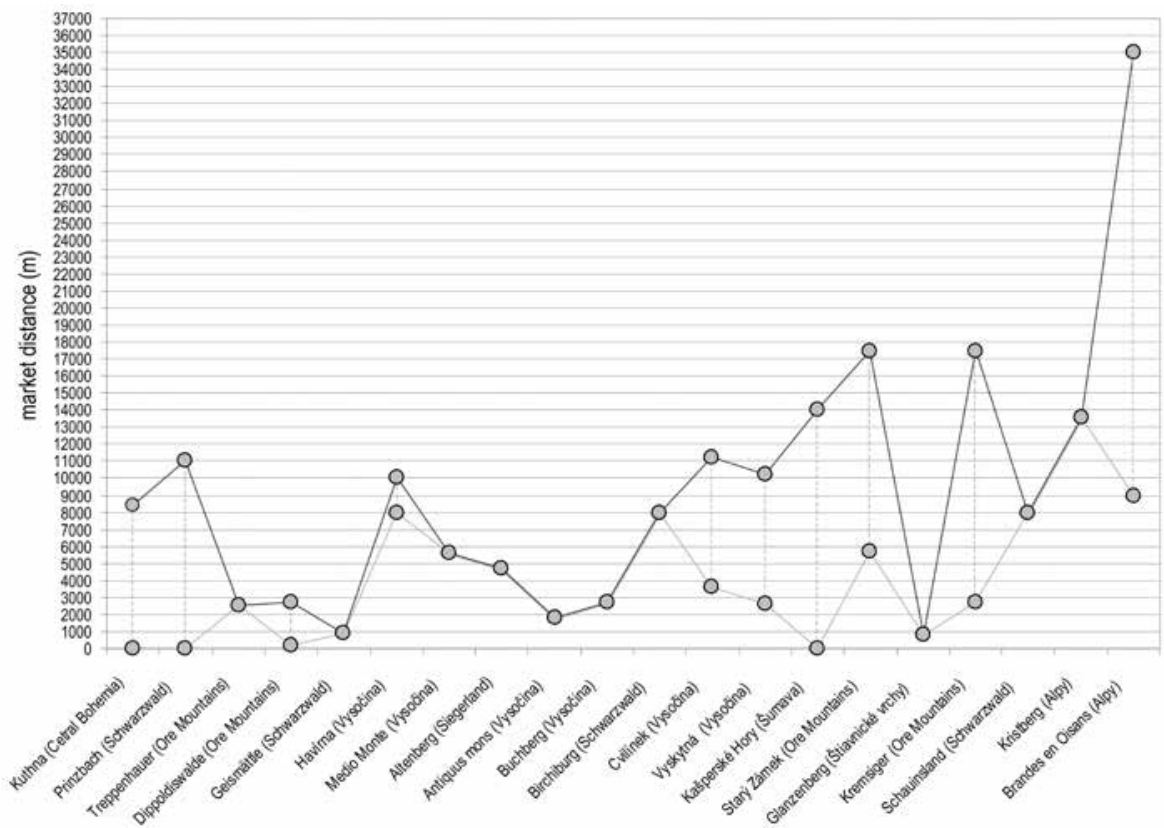

Obr. 19. Graf znázorňující prostorový vztah mezi důlními centry a trhem (městy) v iniciační a pokročilé fázi existence hornických lokalit.

Abb. 19. Diagramm mit räumlichem Bezug zwischen Grubenzentren und Markt (Städten) in der Übergangs- und fortgeschrittenen Phase der Existenz von Bergbausiedlungen. 
(Camelina sativa). Slabě zastoupeny byly plevely chudých kyselých půd odpovídající horské produkci (kapustka obecná a štovík menší). Výskyt teplomilných plevelů (prorostlík okrouhlolistý, dejvorec velkoplodý, čistec roční), vázaných na vápnité půdy, svědčí o dovozu plodin z nížiny. Širší spektrum pěstovaných plodin bylo zjištěno v pylovém diagramu, a sice žito, oves, ječmen, len, konopí/chmel. Pyl však v tomto případě zjevně neodráží lokální produkci, ale pochází z lidských a zvířecích fekálií, a vypovídá tak o konzumovaných plodinách. Ukazuje se, že import plodin nebyl v této nadmořské výšce otázkou velikosti či významu sídliště, nýbrž nezbytností, a to i navzdory vlastní omezené obilnářské produkci (obr. 20-23).

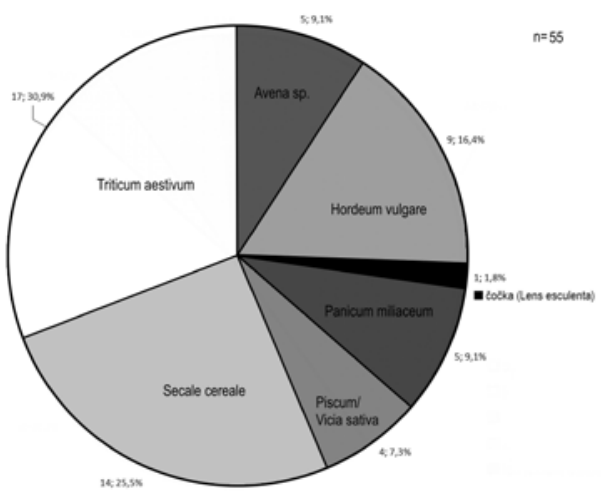

Obr. 20. Graf zastoupení obilovin a užitkových rostlinných druhů $\mathrm{v}$ rostlinných makrozbytcích $\mathrm{v}$ hornickém centru Jihlava - Staré Hory na Českomoravské vrchovině. Analýza P. Kočár a R. Kočárová, výzkum Archaia Brno, o.p.s. Abb. 20. Diagramm mit Vorkommen von Halmfrüchten und Nutzpflanzenarten in Pflanzenmakroresten im Bergbauzentrum Jihlava - Staré Hory auf der Böhmisch-Mährischen Höhe. Analysen P. Kočár und R. Kočárová, Grabung Archaia Brno, o.p.s.

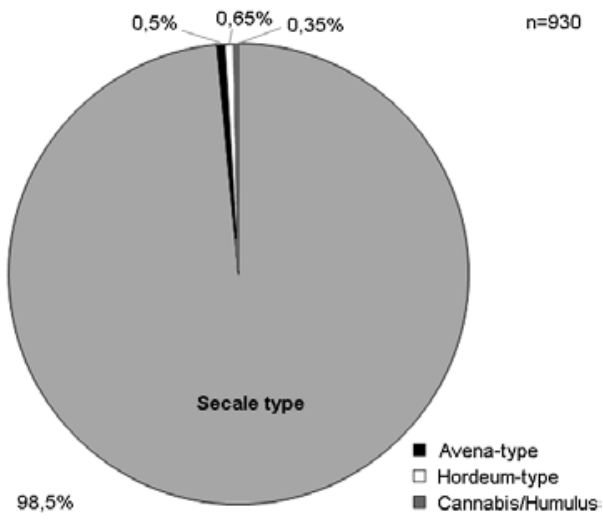

Obr. 22. Graf zastoupení obilovin a užitkových rostlinných druhů v pylovém profilu na lokalitě Starý Zámek. Podle Kočár a kol. 2014.

Abb. 22. Diagramm mit Vorkommen von Halmfrüchten und Nutzpflanzenarten im Pollenprofil an der Fundstelle Starý Zámek. Nach Kočár a kol. 2014.

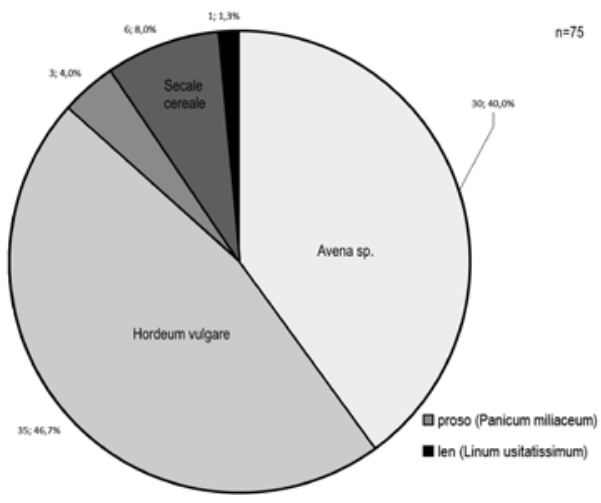

Obr. 21. Graf zastoupení obilovin a užitkových rostlinných druhů v rostlinných makrozbytcích na hornické lokalitě Cvilínek na Českomoravské vrchovině. Analýza P. Kočár a R. Kočárová, výzkum Archaia Brno, o. p.s.

Abb. 21. Diagramm mit Vorkommen von Halmfrüchten und Nutzpflanzenarten in Pflanzenmakroresten an der Bergbaufundstelle Cvilínek auf der Böhmisch-Mährischen Höhe. Analysen P. Kočár und R. Kočárová, Grabung Archaia Brno, o.p.s.

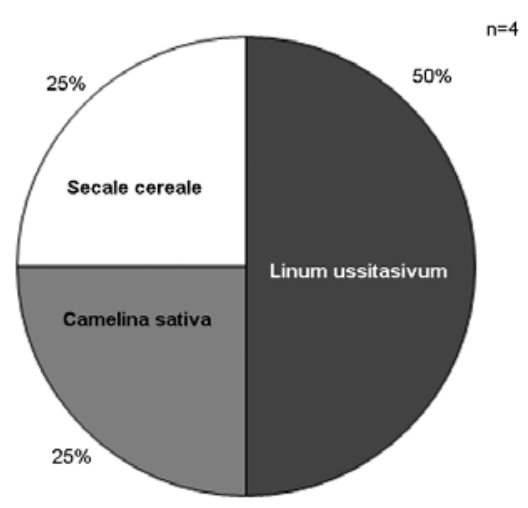

Obr. 23. Graf zastoupení obilovin a užitkových rostlinných druhů v rostlinných makrozbytcích na lokalitě Starý Zámek v Krušných horách. Podle Kočár a kol. 2014.

Abb. 23. Diagramm mit Vorkommen von Halmfrüchten und Nutzpflanzenarten in Pflanzenmakroresten an der Fundstelle Starý Zámek im Erzgebirge. Nach Kočár a kol. 2014. 


\subsection{Ovoce a divoké užitkové druhy: potenciální doplněk obživy}

Nedoceněným zdrojem doplňkové obživy byl sběr a česání lesních plodů. Jejich slabé doklady v paleobotanickém materiálu jistě neodrážejí jejich pravděpodobně nemalý podíl na výživě středověké populace $\mathrm{v}$ horských oblastech. Na prvním místě je třeba jmenovat různé druhy ořechů a oříšků, z nichž na řadě hornických lokalit nalézáme v makrozbytcích zejména lísku. Oříšky byly významným zdrojem tuku, jehož obsah mohl u některých druhů být až $60 \%$. Oř́išky v některých horských oblastech překročily hranici kategorie subsistenční komodity a objevovaly se i na trhu (Úlehlová-Tilschová 1945/2011, 16).

Klíčový význam měly v doplňkové výživě i výkrmu žaludy, které obsahují bílkoviny a asi $35 \%$ škrobu. Ve střední Evropě se jako součást lidské obživy objevovaly i v novověku, a to hlavně v době krizí, například za napoleonských válek nebo za první světové války, kdy byl státem nařízen jejich sběr a zpracování. Hořkosti se zbavovaly vařením, pražením a vyluhováním v horké vodě. Poté se $\mathrm{z}$ nich připravovala mouka, popřípadě se žaludová mouka míchala do obilné. Na východě střední Evropy se ve středověku a v raném novověku plánovitě duby vysazovaly do ovocných sadů a česaly se na sv. Michala (29. záŕí). Zde jsou také v 16. století žaludy, ořechy a bukvice jmenovány mezi odváděnými vrchnostenskými dávkami. V souvislosti s archeozoologickým obrazem některých hornických osad, v nichž je výrazně zastoupeno prase, je třeba uvažovat o žaludech jako o důležitém krmivu. Podobný význam měly bukvice, které byly doplňkovým krmivem také zejména pro prasata. Pro člověka byly, podobně jako oříšky, zdrojem lisovaného oleje. Také bukvice se organizovaně česaly, loupaly a lisovaly. Dubový a ve vyšších polohách pak bukový les je ve středověku i novověku obvyklé udržované pastevní prostředí prasat (Úlehlová-Tilschová 1945/2011, 17-21).

Bez zajímavosti není ani nález bezu černého (Sambuctus nigra) v makrozbytcích v jihlavských Starých Horách. $Z$ jeho bobulí se vařila povidla, popřípadě kaše či omáčka. Vedle toho byl oblíben i bez hroznatý, poprŕípadě nazývaný též červený (Sambucus racemosa), který byl užíván hlavně v horských oblastech, kde se z jeho bobulí po svaření dělal omastek (ÚlehlováTilschová 1945/2011,30). Přítomnost břízy ve většině pylových i makrozbytkových záznamů on site i off site připouští možnost nařezávání jejích kmenů za účelem získávání březové štávy. Ta byla významným zdrojem cukru, přičemž obvyklým způsobem úpravy bylo její zkvašení (Úlehlová-Tilschová 1945/2011, 36). Zdrojem cukru byly i obvyklé lesní plody, jejichž přítomnost (pecičky) je rovněž doložena na většině referovaných lokalit. Jedná se samozrejmě o maliny (Rubus idaeus) a ostružiny (Rubus caesius). Listy štovíku menšího (Rumex acetosella) i štovíku kadeřavého (Rumex crispus), zjištěného opět ve většině archeobotanických záznamů na referovaných hornických sídlištích i v jejich okolí, byly obvyklými př́ísadami do pokrmů, popřípadě složkou zeleninových salátů (Úlehlová-Tilschová 1945/2011, 51-57). Podobné využití měla tradičně kopřiva dvoudomá (Urtica dioica) či hluchavka bílá (Lamium album)

Na krátkodobém hornickém sídlišti Cvilínek na Pelhřimovsku byla doložena jabloň, třešeň ptačí a sbíraná líska, maliník či ostružiník. V jihlavských Starých Horách byly z této skupiny užitkových druhů zastoupeny sbírané druhy ovoce, například maliník a ostružiník křovištní. Totéž platí i o zlomcích skořápek lísky obecné a nažkách jahodníků. Sortiment koření je chudý, čítá pouze nález dvou nažek kopru. Zjištěna byla také trnka, jejíž plody byly užívány v celém středověku. Nálezy švestek, oříšků a lesních plodin známe i z odpadních vrstev na hornickém sídlišti Kristberg v Tyrolských Alpách (Luggin 2003, 71-72).

\subsection{Archeozoologický obraz zvířectva ve středověkých hornických osadách}

Pro hornická sídliště je typické extrémně malé zastoupení osteologických nálezů, tř̌ebaže chov zvířectva i přítomnost zpracovatelů masa naznačují dobové právní texty. Archeozoologické nálezy z hornických sídlišst' jsou vzácné úměrně špatnému dochování kostí na minerálních půdách. Naprŕíklad na Treppenhaueru kontrastuje s prokopaným objemem archeologických terénů 
jen mizivé množství velmi špatně dochovaných kostí (Schwabenicky 2009, 162; Kenzler 2008, 289).

Na vysokohorském alpském sídlišti Brandes en Oisans ve Francii převažovaly ovce a kozy nad hovězím dobytkem, přičemž $80 \%$ hovězího dobytka bylo poráženo do tří let věku, zatímco zbytek byl snad využit k potahu či dojení (Bailly-Maître 2016). Ovce jsou výrazně zastoupeny i na lokalitě Kristberg v Tyrolských Alpách. Zde ale stále ještě dominuje skot, překvapivě však $20 \%$ kostí tvoří kosti telat. Může to být dokladem úhynu mlád’at, která pak byla konzumována, nebo opravdu vysokého stravovacího standardu tamní hornické komunity (Stopp 2003, 82). Obraz důlního centra Altenberg v Siegerlandu je v tomto ohledu úplně jiný: skot zde byl porážen v ještě vyšším věku než ve městech a jeho kosti vykazovaly dlouhotrvající zatížení (Doll 1998, 173). To je možné vysvětlit tak, že byl více než běžně využíván $\mathrm{k}$ tahu, nebo byl lacino nakupován jako již doživající, opotřebený předchozími majiteli. Na hornickém sídlišti Glanzenberg z 12.-16. století u Banské Štiavnice je situace ovlivněna snadnou dostupností trhu. Zde byly patrně nakupovány především méně masité (levnější) partie samců tura středního věku. Vzhledem $\mathrm{k}$ nejistému původu dobytka není jasné, zda opotřebení koster svědčí pro konzumaci poražených tažných kusů, či dobytka z okolních vesnic. Ojedinělé nálezy kostí samic a telat sice nevylučují ani vlastní chovy, ty však podle počtu konzumovaných jedinců hrály ve výživě horníků jen podružnou roli (Bialechová-Labuda 2017, 43-45).

V domácím prostředí určitý obraz nabízí nevelký osteologický soubor z jihlavských Starých Hor v srdci Českomoravské vrchoviny. V souboru 2698 fragmentů kostí byli pouze jedním procentem zastoupeni koně domácí. Vedle toho ovšem zaujme 862 fragmentů kostí velkých kopytníků, v čemž je možné vidět širší spektrum různých plemen tažných mezků, mul apod. Domácí kopytníci ovšem mohou být statisticky „ztraceni“ i v dalších 55 fragmentech blíže neurčených středně velkých savců. Na jednom žebru takového kopytníka byla zaznamenána zhojená zlomenina. Nejvíce byl zastoupen tur domácí (57\%). Jednalo se nejméně o 28 jedinců, z toho 23 jedinců adultních, tři subadultní a dva juvenilní. Mezi ostatky patř́cími dospělým kusům byly snad i tři krávy, přičemž šlo spíše o malá plemena. Na jednom nálezu prstního článku byly nalezeny výrazné úpony, které lze považovat za patologické změny způsobené přetěžováním zvířete v tahu. Dalším nejpočetněji zastoupeným zvířetem bylo prase domácí (32\%). Z rozlišených devatenácti jedinců byli dva adultní, z toho jedna prasnice. Třináct jedinců bylo subadultních, z čehož deset byli samci a čtyři juvenilní kusy. Podle stavu chrupu lze odhadnout stáŕí prasat od 4 do 36 měsíců. Velikostně byla zdejší prasata spíše menšího vzrůstu. Dále bylo rozlišeno 76 fragmentů kostí ovce/kozy (6\%) a jeden fragment prokazatelně kozy domácí. Šlo nejméně o devět jedinců, z nichž tři byli dospělí, tř̌i subadultní, dva juvenilní a jeden kus neonatální až velmi juvenilní. Kohoutkovou výšku kozy lze odhadovat na $63 \mathrm{~cm}$. Dvacet osm zlomků kostí patřilo nejméně pěti dospělým kurům domácím a deset fragmentů asi kuřatům $(3 \%)$. V jednom případě byla zastoupena dospělá husa domácí. Lovnou zvěř $(0,3 \%)$ zastupují tři fragmenty kostí zajíce polního. Zatímco u většiny druhů byli zjištěni dospělí i nedospělí jedinci a u ovce/kozy dokonce i neonatální jedinec, u domácích kopytníků pozorujeme jen dospělé kusy. Převaha dospělých kusů je zjevná i u tura domácího, naopak třeba u prasete převažují kusy nedospělé. Ty byly zužitkovány na maso, tuk, šlachy, kůži, kosti apod. Z tohoto pohledu zaujme $15 \%$ souboru kostí se záseky, zářezy a stopami odseknutí, a to hlavně na žebrech, dlouhých kostech, na pletencích a krátkých kostech končetin či na obratlích. To pozorujeme hlavně u tura domácího a pak kupodivu nikoliv třeba u prasat, nýbrž u velkých kopytníkủ. Méně byli porcováni stř̌edně velcí savci, ovce/kozy, ve dvou případech koně a jednou kur domácí. Zjištěny byly i kosti opálené, mohlo by se jednat o důsledek opékání masa, ale vyloučeno není ani pálení uhynulých kusů. Toto pozorujeme nejvíce na kostech velkých kopytníků, méně u tura, prasete, a na dvou kostech středně velkých savců (Sủvová 2012).

Na lokalitách Kremsiger a Starý Zámek v centrální části českých Krušných hor tvoří kosti a zuby tura a větších savců (nejspíše rovněž tur) přes polovinu kostí (Kyselý 2015). Na Kremsigeru se jedná u kusů s určitelným stářím převážně o mladé jedince. Na hornickém sídlišti je v početnosti následují kosti prasete, na hutništi koně, a dále jednotlivými kusy kosti ovce či kozy 
a kura (obr. 24-26). Podobně jako na Cvilínku jsou makrozbytky doloženy pastviny a kosené louky. Pyl v hnojovitých vrstvách snad vypovídá o přikrmování tahounů ovsem a ječmenem (Kočár a kol. 2014).

U menší hornické osady na Cvilínku na Českomoravské vrchovině je nápadná úplná absence osteologického materiálu. Nepřímou metodou indikace živočišné produkce tak zůstává analýza rostlinných makrozbytků. Třeba zjištěné obilniny oves a ječmen byly v minulosti využívány jako jádrové krmivo koní a soumarů, jejichž uplatnění bylo v hornictví značné. Indikátorem pastvy je nejen jalovec, nýbrž i některé druhy nízkostébelných porostů vícesečných luk a pastvin. Průhony dobytka osidluje též doložená ostřice zaječí (Hrubý a kol. 2014, 187, 198, 209, 212). Jestliže pastvu nepř́ímo dokládají určité plevele, doklady ustájení či ohrad postrádáme (k pastvě Schwabenicky 2009, 162, Abb. 334). Jediná, nikoliv zcela jednoznačná ohrada byla zatím nalezena na sídlišti Brandes en Oisans ve francouzských Alpách (Bailly-Maître 2016). K archeologickým dokladům hospodářského zvířectva patří soubor použitých podkov ze Cvilínku a z důlního areálu z druhé poloviny 13. století u Opatova západně od Jihlavy na Českomoravské vrchovině.

\section{Diskuse a závěry}

\section{1 Úvaha nad dalšími okolnostmi slabého postavení vlastního obilnářství hornických center}

Nepř́iznivé přírodní prostředí, které řadu důlních center na vysočinách a v horách obklopovalo, samo o sobě nesnižovalo obilnářský potenciál jejich zázemí (obr. 18). Nad výškovou hranicí smysluplného obilnářství alespoň v subsistenčním měřítku (okolo $800 \mathrm{~m}$ ) ležela jen alpská hornická sídliště jako Kristberg (1 $190 \mathrm{~m})$, Brandes en Oisans (1 $800 \mathrm{~m})$, popř́ípadě báňský komplex v oblasti Schauinsland ve Schwarzwaldu (ca $1100 \mathrm{~m}$; Straßburger 2015). Přesto však zejména u krátkodobých sídlišt' v českomoravském prostoru pozorujeme zúženou skladbu obilovin i dalších užitkových druhů. Příčinou zanedbatelné role vlastního obilnářství bylo soustředění pracovních sil do produkce kovů. Jistou rezervu pracovníků, které bylo možné vyčlenit pro subsistenční zemědělství, mohl generovat samotný směnný provoz, kdy všichni horníci nebyli vždy současně pod zemí, a dále jejich rodinní příslušníci. I ti však, jak víme, byli zaměstnáni při úpravě vytěžených hornin a jejich dalším zpracování, nařízení o maximálně jedné směně pod zemí byla zřejmě překračována.

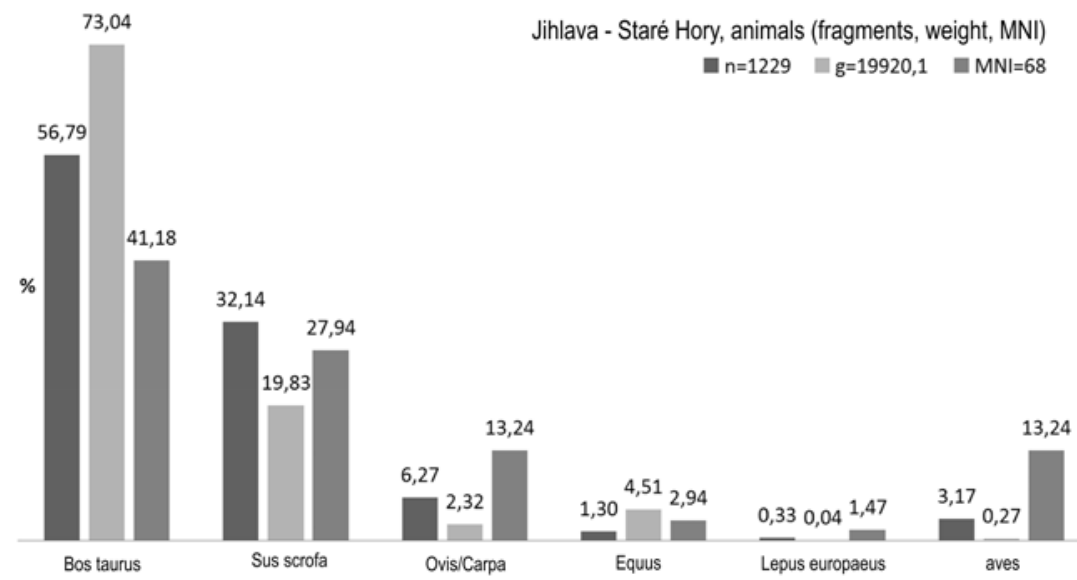

Obr. 24. Graf zastoupení druhů zvířat v osteologickém materiálu na lokalitě Jihlava - Staré Hory na Českomoravské vrchovině. Analýza Z. Sůvová (2012), výzkum Archaia Brno, o.p.s.

Abb. 24. Diagramm mit den im osteologischen Material vertretenen Tierarten an der Fundstelle Jihlava - Staré Hory auf der Böhmisch-Mährischen Höhe. Analyse Z. Sůvová (2012), Grabung Archaia Brno, o.p.s. 


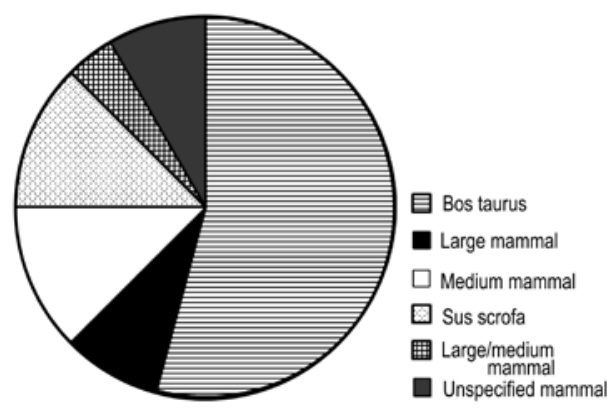

Obr. 25. Graf zastoupení druhů zvířat v osteologickém materiálu na lokalitě Kremsiger v Krušných horách. Podle Kyselý 2015.

Abb. 25. Diagramm mit den im osteologischen Material vertretenen Tierarten an der Fundstelle Kremsiger im Erzgebirge. Nach Kyselý 2015.

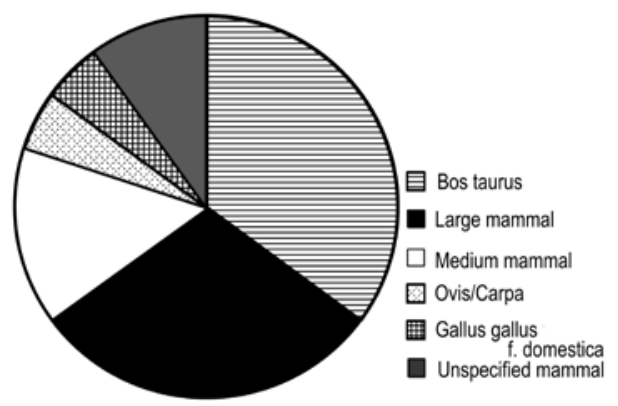

Obr. 26. Graf zastoupení druhů zvírat v osteologickém materiálu na lokalitě Starý Zámek v Krušných horách. Podle Kyselý 2015.

Abb. 26. Diagramm mit den im osteologischen Material vertretenen Tierarten an der Fundstelle Starý Zámek im Erzgebirge. Nach Kyselý 2015.
Hlavním důvodem neexistence vlastního obilnářství hornických osad byla ale jasná právní hranice mezi specifickým a krátkodobým užíáním země $\mathrm{v}$ přímé souvislosti s hornickou činností a mezi různými formami vlastnictví půdy: obyvatelé hornických osad vlastníky ani nájemníky okolní zemědělské půdy nebyli, a neměli proto právo tuto půdu obdělávat. Při životní náplni obyvatel středověkých důlních center, jejichž společenský status byl definován profesní příslušností a vyznačoval se osobní svobodou, projevující se mimo jiné migrací za prací, nedávalo držení a obdělávání plužiny žádný smysl. Přičteme-li k uvedenému i skutečnost, že jádra hornických sídlišst' se v závislosti na aktuálně dobývaných, či naopak opouštěných úsecích rudních žil zpravidla posouvala, pak je zjevné, že předpoklady pro vznik jakési pravidelně obdělávané „hornické“ plužiny bytostně chybí. Tím se tyto osady také liší od měst, $\mathrm{k}$ nimž naopak plužina náležela, a kdy středověká města se na obilnářství $\mathrm{v}$ různé míře plánovaně podílela.

Výpověd' makrozbytků na hornických sídlištích může za ideálních podmínek podle poměru extrazonálních plodin $\mathrm{k}$ plodinám lokálním a podle míry nevymláceného a vymláceného obilí naznačovat dálkový dovoz, ale i rozlišit dovoz od zpracování obilí na místě, tedy snad z vlastních zdrojů. Podíl pšenice $\mathrm{v}$ chlebovém obilí ve výše položených sídlištích ukazuje na rozdíly v zásobování. Tak v jihlavských Starých Horách dosahuje podíl pšenice, považované za extrazonální plodinu, celých $30,9 \%$ a čočky $1,8 \%$, na druhé straně výskyt nezpracovaného žita i pšenice může znamenat i částečnou lokální produkci (Hrubý a kol. 2014, 131, graf 17). Může to být důkazem lidnatosti Jihlavska, které nejspíš překročilo možnosti samozásobitelství, může jít také o indicii ekonomické síly Jihlavy, dovolující nákup výživnější pšenice. Motivem dovozu různých druhů potravin přitom nemuselo být vždy jen nezbytné přežití, nýbrž i preference určitých komodit movitějšími jedinci, třebaže to se mohlo dít krátkodobě, př́ležitostně, či dokonce jednorázově. Připomeňme ve 13. století přítomnost kardamomu v báňském centru Johanneser Kurhaus u města Clausthal-Zellerfeld v Harzu, nebo vinné révy a broskve v tyrolském středisku Kristberg, poprrípadě broskve na lokalitě Brandes en Oisans v Alpe d'Huez (Alper-Römer-Strehl 2003, 349; Luggin 2003, 71-72; Bailly-Maître 2016).

Kriticky je třeba myslet na obecně platnou zákonitost, že ne u všech nálezů makrozbytků se musí vždy nutně jednat o doklady potravinářského využití. Víme třeba, že obilná sláma byla běžným stavebním materiálem, přidávaným do výmazů a omazů sroubených a hrázděných staveb. Př́́kladem může být hornické sídliště z raného 13. století v Dippoldiswalde, kde byly v jedné ze zemnic nalezeny zuhelnatělé zlomky mazanic se stébly slámy, obsahující plevely i pupeny obilí, ale také třeba zuhelnatělý provaz z rostlinných vláken (Herbig 2012; Rösch a kol. 1994; Schubert a kol. 2014, 201-202). 


\subsection{Doklady přitomnosti zviŕat a otázka vlastních chovi $i$ živočišné výroby}

Jateční chov se v prostředí vrchovin a hor jeví jako výhodnější z hlediska nároků na lidskou práci a byl podle toho tedy výhodnější i pro hornická sídliště. Převahu chovného hospodářství nad obilnářstvím naznačují ve světě středověkých horníků ostatně i uváděné písemné prameny, které se zmiňují výhradně o pastvinách. U hornických osad je však třeba uvažovat jak o jatečním chovu mladých kusů, tak o chovu tahounů i soumarů, přičemž ve výše zmíněných údajích o zřizování pastvin se může docela dobře skrývat obojí. Lze se toliko domnívat, že z hlediska zajištění provozu dolů, úpraven a hutí, nebo z hlediska zajištění dopravy rud, paliv, stavebního dřeva apod., měla prioritu zvířata pracovní. Na druhé straně ale např́íklad dospělá koza, doložená v osteologickém materiálu z jihlavských Starých Hor, představuje jen stěží jateční anebo dokonce pracovní zvíře, smysl tedy dává její chov na mléko. Koza je zároveň typickým zvířetem chudšího individuálního hospodáře, který má k vypásání jen menší, fragmentarizované a reliéfně nevýhodné plochy.

Vlastní jateční či mléčný chov v hornických osadách byl nejspíš malý, individuální a plně subsistenční. Mohl doplňovat standardní jídelníček a nejspíš představoval i nouzovou potravinovou rezervu v době výpadku trhu, zásobování či obecně nedostatku, at' už byly jeho příčiny jakékoliv (válečné události, neúroda, mimořádně dlouhá zima se sněhovou pokrývkou, nesjízdné cesty apod.). Převaha skotu nad prasetem odpovídá obrazu, který známe i z měst, stejně jako převaha jatečního věku skotu nejčastěji v rozmezí 2-4 let (Nývltová Fišáková-Procházka-Sůvová 2016, 131, 141). Z hlediska reálné spotřeby masa konkrétním střediskem je pak třeba rozlišovat mezi vlastní subsistenční jateční produkcí a mezi plánovaným systematickým zásobováním. To se dá předpokládat u těch center, kde se v praxi uplatnilo výše pojednávané právo zřízení masných krámů (Tomaschek 1897, 66 č. 93) a kde fungoval blízký i vzdálený trh. Dotace šestnácti parcel na hornickém sídlišti jedním řezníkem odpovídá poměrům ve městech. Menší městečka jako Český Brod měla kolem dvaceti masných krámů, v přelidněné Praze naopak připadal jeden zhruba na 187 obyvatel. Ve vyhrazených dnech směli cizí řezníci - „huntýři“ prodávat již zbourané nasolené maso (Hoffmann, F. 2009, 239-240).

U dospělých jedinců koně, neurčených kopytníků a zčásti i tura domácího nutno předpokládat především tah v zápřahu či soumarové využití. U dospělých kusů dalších zjištěných zvířat (s výjimkou prasete) lze s opatrností předpokládat i chov na mléko a vlnu. Po dosloužení nebo uhynutí byly ovšem jak pracovní, tak dojné kusy pravděpodobně zužitkovány na maso, kůži, kosti, rohy a kopyta. V jihlavských Starých Horách byl třeba zaznamenán šikmo řezaný zlomek pravé lopatky tura domácího, kterou snad můžeme považovat za odpad či polotovar při výrobě nářadí či nástrojů (Sůvová 2012). U kůží se vedle běžného využití musí na hornických lokalitách předpokládat výroba transportních a čerpacích vaků větších rozměrů, což znamená zpracování kůží z větších kusů hovězího dobytka, telat či koní. Př́íkladem toho je hornické středisko ze 13. století Altenberg v Siegerlandu (Viereck 1998, 140). Významné mohlo být v prostředí důlních center využití poražených či uhynulých kusů hovězího dobytka pro výrobu loje do lampiček (Doležalová 2012). Kur domácí i kuřata v osteologickém souboru v jihlavských Starých Horách nevybočují z běžného subsistenčního hospodaření. Navíc může jít i o doklad účelového nákupu drůbeže za účelem konzumace.

Z hlediska opatřování masité potravy pak lze v hypotetické rovině uvažovat také o blíže nestanovitelném, přesto však dost možná nemalém podílu drobného kolektivního lovu, který byl tradičně spojen právě s pastevním hospodářstvím. Děti a dorostenci, zcela samozřejmě zapojení do hospodářství dané komunity, si sami opatřrovali doplňkovou potravu chytáním, líčením pastí, kamenováním či jinak. Touto potravou byly standardně drobní savci jako zajíc, králík, sysel či veverka. Samozřejmostí byly ryby a raci, ale i vrány a další druhy ptáků. Konečně potravou z dnešního pohledu přinejmenším neobvyklou, avšak dobově zcela normální byli v tomto smyslu také žáby, hlemýždi a slimáci. Úprava uvedené potravy byla jednoduchá a zpravidla se odehrávala přímo na dané pastvě (Úlehlová-Tilschová 1945/2011, 57-63). 


\subsection{Hornická sídliště, hospodářství a trh}

Ze zjištění zanedbatelného podílu vlastního obilnářství i omezených vlastních chovů vyplývá značná role zásobování hornických center prostřednictvím trhu. Krámy i práva na zřízení trhu bývají někdy interpretovány jako doklad městského charakteru hornických sídlišt' (Schwabenicky 2009, 204-214; Tomaschek 1897, 66 č. 93). Domníváme se ale, že tak jako neexistuje jednotná definice topografických a archeologických vlastností města, neexistuje ani měřítko, podle kterého by bylo možné určovat, zda to či ono hornické sídliště bylo či nebylo městem. Úvahy o urbanismu hornických sídlišt' jsou důsledkem neúplného pochopení jejich prosperitního charakteru. Tyto areály jsou na straně jedné osadami pracovními, na straně druhé však právě úzké výrobní zaměření předurčuje spotřební, tj. paradoxně nevýrobní ráz jejich hospodářství. Vyprodukovanou protihodnotou uspokojení životních potřeb obyvatel hornických osad nebyly řemeslné či zemědělské produkty, nýbrž mzda za práci v dolech, úpravnách a hutích (CIB I, 295). Skutečným městem se hornické sídliště stávalo výjimečně, třebaže nejedno z nich některé městské funkce v době svého rozkvětu mohlo plnit. Transformace hornické osady ve skutečné město, které si tuto úroveň udrželo trvale, mohla proběhnout jen díky souhře více okolností. Předpokladem byla přirozená centralita zdůrazněná nejlépe absencí rozvinutého městského organismu v okolí. Potřebný byl i vlastní silný lidský potenciál, což bylo prrímo podmíněno objemem důlní činnosti a perspektivou jejího pokračování. Další podmínkou bylo zapojení hornické osady do regionálního trhu a dostatečný podíl řemeslné i zemědělské činnosti v její ekonomice (Schwabenicky 2009, 207, 2). Takovým vývojem ještě na sklonku 12. století prošel Freiberg a do poloviny 13. století také Dippoldiswalde (Hoffmann-Richter 2012; Hoffmann, Y. 2011; Schubert-Wegner 2015). Podobný byl i vývoj Banské Štiavnice (Labuda 2004). U nás možno zmínit př́íklad Kutné Hory (Frolík-Tomášek 2002; Žemlička 2014, 360-367; Velímský 2007; 2012; Velímský-Končelová 2012) nebo Kašperských Hor (Schneiderwinklová 2000, 15-19, 26-28, 30-32; Kašák 2012, 26-45, 50-53). Zásobování stř̌edověkých hornických center zemědělskými a potravinářskými produkty mohlo být $\mathrm{v}$ zatím nezjištěné míře saturováno vlastní produkcí, klíčová však byla role lokálního trhu. Uvažovat lze i o nákupu zboží ze vzdálenějšího trhu a o tzv. truckovém systému, tedy výplatě v naturáliích, s čímž se lze v Krušných horách setkat v raném novověku (Jančárek 1971, 16-18, 87-117). Poměr těchto zdrojů závisel na početnosti komunit, přírodních podmínkách, hustotě zemědělského osídlení, blízkosti cest. Strategie obživy byly nejspíš kombinovány. Zčásti mohla být kauzalita obrácená a hornické osídlení mohlo podněcovat urbanizaci blízkých center, přesměrování cest a snad i vznik zemědělských sídlišt' (obr. 19).

\subsection{Měšt’ané jako držitelé propůjček, horních oficií i zemědělské půdy poblǐz̆ důlních center}

S úrovní trhu, ale hlavně s jeho ovládnutím měštanským živlem přímo souvisí otázka zásobování krámů, především chlebových, a pak šenků (hospitia), které nebyly jen teoretickým právním pojmem. V době konjunktury a pokročilého rozvoje měst od druhé poloviny 13 . století skutečně existovaly: jmenujme třeba důlní střediska Fürstenberg, Ulrichsberg či Ehrenfriedersdorf v saském Krušnohoří (Schwabenicky 2009, 208-209) nebo Buchberg na Havlíčkobrodsku (CDB V/1, 661-662 č. 447). Poněvadž sladovnictví a pivovarnictví bylo výsadou měst, musíme předpokládat, že i dodávky piva do důlních center byly plně v režii zainteresovaných měštanů, jak ostatně ukazuje spor mezi Freibergem a Dippoldiswalde z roku 1266 (viz níže). Z důvodů uvedených v dalším textu se však lze domnívat, že v rukou měštanů bylo i zásobování důlních center obilím, chlebem a masem. Navíc to mohli být titíž jedinci, kteří zároveň drželi báňské úřady i samotné propůjčky na horách.

Zemědělskou půdu v blízkosti důlních podniků a zároveň v rukou měštanů, zainteresovaných v produkci drahých kovů, můžeme v rozvinuté fázi důlní ekonomiky i trhu sledovat $\mathrm{v}$ tzv. Velkém brodském privilegiu z 8 . června 1278. V něm se v $\S 61$ uvádějí polnosti náležející $\mathrm{k}$ městu, včetně držby jednotlivých měšt’anů (CDB V/2, 602, 608 č. 873). Nalézáme zde lány, dvory i celé vsi patř́icí důlním podnikatelům nebo držitelům báňských úřadů, tzn. mincmistrům, 
urburéřům, správcům a písařům mince, nebo zkoušečům. Jedním z nich je např́íklad Klaric (agris Claritii), který byl roku 1296 mincmistrem pro Čechy. Také jméno Ekhard (laneus Eccehardi) lze pravděpodobně spojit s Ekhartem, jedním z mincmistrů pro Čechy za Václava II. Nalezneme zde dále jména Jindřich Puš (curia Heinrici Bihusshen), Hamman Ryšavý (curia Hammani Rufi) anebo Konrád Herstul (curia Cunradi Herstul) patřící rovněž nájemcům klíčových báňských úřadů (Jan 2006, 92-94, 101-109, 111, 119). Další z držitelů polností Wernher by mohl být $\mathrm{s}$ opatrností ztotožňován $\mathrm{s}$ Wernerem Lotingem, držitelem propůjčky z 23. října 1272, kterou přijal s opatem želivského kláštera (CDB V/2, 320 č. 681). Nalezneme zde i pole „starého pana Eberharda“ (agri domini Eberhardi Antiqui), se vší pravděpodobností někdejšího význačného mincmistra Eberharda z padesátých a šedesátých let 13. století (Jan 2006, 103, 130; Hoffmann, F. 1980; Žemlička 2011, 229-231).

Dědičnou držbu lánů mincmistry i důlními podnikateli odráži i Pohledský urbář, sepsaný okolo roku 1328. Mezi desátky ze vsi Bartoušov nalezneme jméno Vreyberger, shodné se jménem někdejšího držitele propůjček na Havlíčkobrodsku, z nichž ta nejstarší je ovšem z roku 1258 (CDB V/1, 269 č. 168). Dalším jménem je Creuzpurger, což by mohl v extrémním případě být někdejší mincmistr, činný ještě před polovinou 13. století (Somer 2016, 26-27).

Nezcizitelné a dědičné držení půdy v tomto duchu naznačuje i listina z 13. prosince 1252, vydaná vyšehradskou kapitulou pro mincmistra Jindřicha v Humpolci (Heinrico magistro monetae in Gumpolz). Jindřich obdržel území na Humpolecku táhnoucí se k masivu Melechov (inter metas ville de Gumpolz et silvam Nelecho circa Zagraticam), aby zde do konce roku 1253 vytyčil lány a usadil svěřené kolonisty. Prvních pět let byli osadníci osvobozeni od všech plateb, v šestém roce již měli odvádět desátek z pšenice, žita, ječmene a ovsa. Po uplynutí desetileté lhůty byl každý lán zatížen platbou čtvrt hřivny stř́ibra ročně. Mincmistr si směl v dědičné držbě ponechat sedmý a osmý lán. Zboží nesměl nijak zcizit a v př́ípadě prodeje je musel nejprve nabídnout kapitule (CDB IV/1, 436-437 č. 256; též Klápště 2005, 228-230). Nové lány mincmistra Jindřicha mají být zatíženy ročním desátkem čtvrt hřivny, což jsou čtyři loty (ca 63,3 g) stř́bra. Kapitula přitom výslovně trvala na tom, aby výměra lánů, které Jindřich u Zahrádky na Humpolecku vytyčí, odpovídala německým lánům na želivském klášterním panství. O půlstoletí později popisuje podobný lokační projekt na želivském klášterním panství severozápadně od Jihlavy listina z 5. prosince 1303, v níž se uvádí částka 6 lotů stř́ibra z lánu ročně (CDM V, 149 č. 145). Pozorovaný rozdíl dvou lotů stříbra za lán nejspíš nespočívá v rozdílné velikosti lánů, ani v rozdílné kvalitě půdy, nebot' se jedná o zcela srovnatelná území, ale spíše je výsledkem rozdílných cenových poměrů v odstupu padesáti let. Zcela jiné poměry však panovaly v Posázaví na Havličkobrodsku, kde výše zmíněná brodská listina z roku 1278 hovoří o desátku ve výši dokonce půl hřivny stř́ibra $\mathrm{z}$ lánu (8 lotů, ca $126,5 \mathrm{~g}$ ).

Můžeme nyní diskutovat, zda uvedené př́iklady ukazují pozemkovou držbu v souvislosti s výkonem úřadu, nebo jde o součást běžného jevu zakupování se měštanů na venkově, kdy koupě zemědělské půdy byla pro ně formou investice a trvalým pojištěním majetku (Kejř 1998, 187-193). V hornických oblastech mohly svou roli hrát zcela praktické důvody. V počátečních fázích těžby, zejména $v$ rudních revírech, kde se zemědělská infrastruktura a trh teprve rodí, stál mincmistr nejednou před úkolem důlní činnost vůbec nastartovat a zorganizovat po stránce vypořádání nároků držitelů půdy i po stránce materiálních, finančních a lidských zdrojů. Právě to bylo spojeno s příchodem množství lidí, jejichž obživu a zásobování bylo třeba dlouhodobě zajistit. Řešením byla vlastní kolonizační činnost, která zvýšila výměru zemědělské půdy i počet zemědělsky činného obyvatelstva v dotyčné hornické oblasti. Teprve později se pozemková držba v rukou zainteresovaných úředníků i etablovaných důlních podnikatelů mohla stát prostředkem zvyšování vlastních příjmů dodávkami obilí, piva, masa a dalších potravin na doly. Důlní podnikatelé a držitelé oficií nepochybně uměli své zdroje diverzifikovat a nesoustředili se jen na zisky ze samotné produkce kovů. K principu ovládání zásobování důlních center měštany se určitě vztahuje listina míšeňského markraběte Jindřicha Jasného z 1. září 1266, v níž vladař řeší spor mezi měštany z Freibergu a Dippoldiswalde o práva dodávat pivo a další potřebné zboží na doly (... cerevisia ... et omnia et singula, qui in montibus lucrativis sunt in necessaria...; CDS 
II/12, 19 č. 25). Povolením zřizovat šenky v důlních centrech z tohoto pohledu práva měst narušena nebyla, poněvadž se tím v principu nesnižovaly zisky měst, ani jednotlivých měštanů, spíše naopak. Tuto praxi v rozvinuté podobě naznačují ve 14. století privilegia, podle nichž je vrchnost měst př́ijemcem plateb ze skladů a distribuce alkoholu (šrotéřství), chlebných a masných krámů, a to ve městě i na přilehlých dolech. Příkladem může být privilegium z roku 1339 pro Šumburky v Př́isečnici (šrotéřství) či z roku 1362 pro Havlíčkův Brod, v němž jsou zmiňovány výnosy ze šrotéřství, lázní, masných a chlebných krámů ve městě i v hornických centrech (Balášová-Burghardt 2014, 173-174; CIM II, 574-575).

\subsection{Krátký účelový exkurs do raného novověku}

Kriticky a jen s opatrností lze za určitých okolností při řešení dané problematiky ve 13.14. století přihlížet k mladším analogiím, jakými jsou především dolové účty z konce 15. a první poloviny 16. století. Je jasné, že obchodně distribuční vztahy mezi doly a rozvinutým trhem, jakož i množství a spektrum materiálu, objednávaného na doly z měst či od specializovaných producentů na venkově, se v raném novověku od situace ve 13. století podstatně liší. Tak naprŕíklad dřevo, které podle jihlavského horního práva i Ius regale montanorum mohou horníci volně těžit v okolí, se na kutnohorské doly v 16. století nakupuje. U dolů patří mezi technicky využívané živočišné produkty jinak potravinářského charakteru, např́iklad lůj do lamp, který si dělníci sami kupovali (Křepelková 1957, 79), nebo sádlo na mazání vozů a čepů (Ladová 1960, 129). Na přelomu 15. a 16. století se v Kutné Hoře vedla také tzv. koňská registra o nákupech koní pro doly. V dolových účtech nalezneme zápisy o výdajích za lůj, za seno a oves pro důlní koně nebo výplaty sekáčů, kteří na loukách seno kosili a sušili (Ladová 1960, 123, 124, 128-129, 133). Také z prostředí nově založených dủlních středisek v Krušných horách máme určité informace o výživě a hospodářství. Pouze v okolí Měděnce a Nejdku je doloženo omezené obilnářství (oves a ječmen). Jinde zajištovalo vlastní potravinářskou produkci jen dobytkářství, ale zřejmě jen na subsistenční úrovni (zdá se, že vedle hovězího dobytka hrály významnou roli kozy), zatímco za normálních okolností byla i masitá strava zajištěna importem. Charakteristická je situace Oloví, jehož představitelé žádají roku 1563 císaře, aby zařídil ponechání dobytka jako pojistku proti hladovění chudších obyvatel (Jančárek 1971, 90-92). Jestliže živočišnou produkci pro horní centra zde mohly zajistit okolní horské vsi, z obilnin byl ve výše položených vsích na Př́isečnickém panství vyséván prredevším oves, zřejmě jako jádrové krmivo (Maur 1983, 220). Podobně motivovaný chov dobytka a doplňkové až zahradnické obilnářství při dominantním zásobování importy jsou dobře představitelné i pro hornická sídliště vrcholného středověku.

\section{Prameny}

CDB V/1: Codex diplomaticus et epistolarius regni Bohemiae. Tomus V/1 (1253-1266) (Šebánek, J.-Dušková, S., edd.). Pragae 1974.

CDB V/2: Codex diplomaticus et epistolarius regni Bohemiae. Tomus V/2 (1267-1278) (Šebánek, J.-Dušková, S., edd.). Pragae 1981.

CDB VI/1: Codex diplomaticus et epistolarius regni Bohemiae. Tomus VI/1 (1278-1283) (Sviták, Z.-Krmíčková, H.-Krejčíková, J.-Nechutová, J., edd.). Praha 2007.

CDM V: Codex diplomaticus et epistolaris Moraviae, Opus posthumum Antonii Boczek. Tomus quintus ab annis 1294-1306 (Chytil, J., ed.). Brunae 1850.

CDS II/12: Codex Diplomaticus Saxoniae, Urkundenbuch der Stadt Freiberg in Sachsen. Band I. (Ermisch, H., ed.). Leipzig 1883.

CIB I: Codex iuris Bohemici, Tomus Primus. Aetatem Přemyslidarum continens (Jireček, H., ed.). Pragae 1867.

CIM II: Codex juris municipalis regni Bohemiae II. Privilegia královských měst venkovských v království Českém z let 1225-1419 (Čelakovský, J., ed.). Praha 1895.

TOMASCHEK, J. A., ed., 1897: Das alte Bergrecht von Iglau und seine bergrechtlichen Schöffensprüche. Innsbruck. 


\section{Zprávy}

CRKAL, J., 2017: Zaniklé hutnické areály v poloze Altes Schloss / Starý Zámek u Kovářské. Výsledky povrchového a archeologického výzkumu 2010-2016. Nálezová zpráva čj. 401/17, ulož. v archivu ÚAPPSZČ v Mostě.

HENDRYCHOVÁ, L.-KOČÁR, P., 2007: Jihlava - Plus - Staré Hory. Nálezová zpráva o archeobotanické analýze, ulož. v archivu Zip, o.p. s., Plzeň.

KOČÁR, P.-KOČÁROVÁ, R., 2005: Jihlava, Staré Hory - U Mlékárny. Nálezová zpráva o archeobotanické analýze, ulož. v archivu ZIP, o.p. s., Plzeň.

KOČÁR, P.-KOČÁROVÁ, R., 2006: Jihlava - U Mlékárny (výzkumná sezóna 2005). Nálezová zpráva o archeobotanické analýze, ulož. v archivu ZIP, o.p.s., Plzeň.

KOČÁR, P.-MIHÁLYIOVÁ, J., 2003: Jihlava dálniční obchvat, zpráva o archeobotanické analýze, ulož. $\mathrm{v}$ archivu ZIP, o.p.s., Plzeň.

KOČÁROVÁ, R.-ŘEŘICHOVÁ, Z., 2007: Jihlava - Staré Hory - Plus (II. etapa zpracování botanických zbytků). Nálezová zpráva o archeobotanické analýze, ulož. v archivu Zip, o.p. s., Plzeň.

KYSELÝ, R., 2015: Determinace zvířecích kostí z lokalit Kremsiger, Starý Zámek I, II a Vysoký kámen v rámci projektu Archaeomontan (2013-2014). Zpráva o archeozoologické analýze, ulož. v archivu ÚAPPSZČ v Mostě.

SŮVOVÁ, Z., 2012: Jihlava - Na Dolech, U Mlékárny a Obchvat, osteologická analýza. Nepublikovaná zpráva, ulož. v ZČU Plzeň.

\section{Literatura}

ALPER, G.-RÖMER-STREHL, C., 2003: Johanneser Kurhaus: ein mittelalterlicher Blei-/Silbergewinnungsplatz bei Clausthal-Zellerfeld im Oberharz. Reihe A, Monographien, Bd. 32. Rahden, Westf.

BAILLY-MAÎTRE, M-C., 2016: Chapitre 3. L'agglomération de Brandes. In: Bailly-Maître, Marie-Christine-Bruno Dupraz, Joëlle, Brandes-En-Oisans, La Mine D'argent Des Dauphins (XIIe-XIVe siècles). Nové vydání [online], 105-152. Lyon.

BALÁŠOVÁ, M.-BURGHARDT, I., 2014: Neznámá listina z roku 1339 jako nejstarší písemný doklad o těžbě stř́ibra v českém Krušnohoří - Eine unbekannte Urkunde aus dem Jahr 1339 als ältester schriftlicher Nachweis von Silberbergbau im böhmischen Erzgebirge. In: Archaeomontan 2014 (Smolnik, R.-Kubenz, S., edd.), 167-175, 175-180. Dresden.

BIELICHOVÁ, Z.-LABUDA, J., 2017: Nálezy zvieracích kostí z výskumu Glanzenbergu, tzv. ,Starého mesta“ v Banskej Štiavnici. In: Zborník Slovenského Banského múzea 25, 30-69. Banská Štiavnica.

DERNER, K., 2017: Vrcholně středověká hornická sídliště se zvláštním zřetelem k lokalitě Kremsiger (k. ú. Př́ísečnice). Nepublikovaná diplomová práce, Ústav pro archeologii FF UK, Praha.

DOLL, M., 1998: Tierknochen. In: Dahm, C.-Lobbedey, U.-Weisgerber, G., Der Altenberg: Bergwerk und Siedlung aus dem 13. Jahrhundert im Siegerland. Band 2. Die Funde, 167-179. Bonn.

DOLEŽALOVÁ, K., 2012: Středověké keramické lampy v Jihlavě a na Starých Horách u Jihlavy - The Mediaeval Ceramics Lamps from Jihlava and from Staré Hory (Altenberg) near Jihlava. In: Stř́ibrná Jihlava 2010. Acta rerum naturalium 12, 211-220. Jihlava.

DOLEŽEL, J.-SADÍLEK, J., 2004: Středověký důlní komplex v trati Havírna u Štěpánova nad Svratkou. Příspěvek $\mathrm{k}$ dějinám těžby stříbra v oblasti severozápadní Moravy ve 13. a 14. století. Výsledky průzkumu v letech 1990-2001, edice písemných pramenů - Mittelalterlicher Bergbaukomplex im Flurstück Havírna bei Štěpánov nad Svratkou. Ein Beitrag zur Geschichte des Silberbergbaus in Nordwestmähren im 13.-14. Jahrhundert. In: Mediaevalia archaeologica 6. Těžba a zpracování drahých kovů: sídelní a technologické aspekty (Nováček, K., ed.), 43-119. Praha - Most.

FROLÍK, J.-TOMÁŠEK, M., 2002: Kutná Hora. Příspěvek archeologie k nejstarší topografii a komunikačnímu schématu města. In: Civitas et villa. Miasto i wieś w średniowiecznej Europie środkowej (Buśko, C.Klápště, J.-Leciejewicz, L.-Moźdioch, S., edd.), 99-106. Wrocław - Praha.

HERBIG, CH., 2012: Archäobotanik auf sächsischen Burgen, Ausgrabungen in Sachsen 3. Arbeits- und Forschungsberichte zur sächsischen Bodendenkmalpflege, Beiheft 24, 200-202.

HOFFMANN, F., 2009: Středověké město v Čechách a na Moravě. Praha.

HOFFMANN, Y., 2011: Die Geschichte von Dippoldiswalde. In: Aufbruch unter Tage. Stand und Aufgaben der montanarchäologischen Forschung in SachsenArbeits- und Forschungsberichte zur sächsischen Bodendenkmalpflege. Beiheft 22 (Smolnik, R., ed.), 95-104. Dresden.

HOFFMANN, Y.-RICHTER, U., 2012: Entstehung und Blüte der Stadt Freiberg. Die bauliche Entwicklung der Bergstadt vom 12. bis zum Ende des 17. Jahrhundert. Halle (Saale). 
HORÁK, J.-KLÍR, T., 2017: Pedogenesis, Pedochemistry and the Functional Structure of the Waldhufendorf Field System of the Deserted Medieval Village Spindelbach, the Czech Republic. Interdisciplinaria Archaeologica Natural Sciences in Archaeology (IANSA) 8 (1/2017), nestr. Dostupné z http://iansa.eu/ papers/IANSA-2017-01-horak_onlinefirst.pdf.

HRUBÝ, P., 2011: Jihlava - Staré Hory. Archeologický výzkum středověkého důlního, úpravnického a obytného areálu v letech 2002-2006. Př́íspěvek ke studiu středověkého rudného hornictví - Jihlava - Staré Hory (Iglau - Altenberg) - Archäologische Ausgrabungen des mittelalterlichen Bergbau-, Aufbereitungs- und Siedlungsplatzes in den Jahren 2002-2006. Zum Studium des mittelalterlichen Erzbergbaus. Dissertationes archaeologicae brunenses pragensesque 9 (Jan Klápště et Zdeněk Měrínský curantibus editae). Praha - Brno.

HRUBÝ, P. a kol., 2012: Hrubý, P.-Hejhal, P.-Hoch, A.-Kočár, P.-Malý, K.-Macháňová, L.-Petr, L.Štelcl, J., Středověký úpravnický a hornický areál Cvilínek u Černova na Pelhřimovsku - Das mittelalterliche Aufbereitungs- und Bergbauareal Cvilínek bei Černov in der Region Pelhřimov, PA CIII, 339-418.

HRUBÝ, P. a kol., 2014: Hrubý, P.-Hejhal, P.-Kočár, P.-Libor, P.-Malý, K., Centrální Českomoravská vrchovina na prahu vrcholného středověku. Archeologie, geochemie a rozbory sedimentárních výplní nivCentral Bohemian-Moravian Highlands on the threshold of the High Middle Ages. Archaeology, geochemistry and the analyses of alluvial sediments. Spisy Filozofické fakulty Masarykovy univerzity - Opera Universitatis Masarykianae Brunensis, Facultas philosophica 422. Brno.

ISENBERG, E., 1998: Pollendiagramm. In: Dahm, C.-Lobbedey, U.-Weisgerber, G., Der Altenberg: Bergwerk und Siedlung aus dem 13. Jahrhundert im Siegerland. Band 2. Die Funde. Denkmalpflege und Forschung in Westfalen. Band 34, 237-238. Bonn.

JAN, L., 2006: Václav II. a struktury panovnické moci. Brno.

JANČÁREK, P., 1971: Města českého Krušnohoří v předbělohorské době: př́íspěvek ke studiu jejich sociální struktury. Ústí nad Labem.

KAŠÁK, K., 2012: Hlubinné dobývání zlata v Kašperských Horách. Nepublikovaná diplomová práce, Katedra archeologie ZČU, Plzen̆.

KEJŘ, J., 1998: Vznik městského zř́izení v českých zemích. Praha.

KOČÁR, P. a kol., 2014: Kočár, P.-Kočárová, R.-Petr, L.-Crkal, J.-Derner, K.-Lissek, P., Rostlinné zbytky z vrcholně středověkých hornických lokalit Krušných hor - Pflanzenreste aus den hochmittelalterlichen Bergbaustandorten im Erzgebirge. In: ArchaeoMontan 2014. Ergebnisse und Perspektiven. Výsledky a výhledy. Arbeits- und Forschungsberichte zur sächsischen Bodendenkmalpflege. Beiheft 29 (Smolnik, R., ed.), 119-135. Dresden.

KLÁPŠTĚ, J., 2005: Proměna českých zemí ve středověku. Praha.

KLÍR, T., 2010: Osídlení horských oblastí Čech ve středověku a raném novověku - východiska interdisciplinárního výzkumu - Die Besiedelung der Gebirgsgegenden Böhmens im Mittelalter und der frühen Neuzeit - Ausgangspunkte für eine interdisziplinäre Forschung, AH 35, 373-391.

- 2016: Zaniklé středověké vsi ve výzkumném záměru Ústavu pro archeologii Univerzity Karlovy v Praze. Zaniklý Spindelbach (Krušné hory), Kří a Hol (střední Čechy). In: Wieś zaginiona: stan i perspektywy badań (Nocuń, P.-Przybyła-Dumin, A.-Fokt, K., edd.) [online], 17-58. Chorzów.

KŘEPELKOVÁ, A., 1957: Př́íspěvek k hospodářským a sociálním dějinám kutnohorských havířů na sklonku XV. a v první polovině XVI. století, Středočeský sborník historický $1,67-83$.

LABUDA, J., 2004: Banská Štiavnica ako príklad osídl'ovania banských regionov - Banská Štiavnica als Beispiel für die Besiedlung der Bergbauregionen, AH 29, 261-266.

- 2016: Glanzenberg v Banskej Štiavnici. Archeologický výskum zaniknutej lokality. Krupina.

LADOVÁ, M., 1960: Kutnohorské rejstříky počtů dolových 1472-1532, Př́íspěvky k dějinám Kutné Hory 1, $121-146$.

LOBBEDEY, U., 1998: Zeitstellung, Struktur und Bedeutung der Bergbausiedlung Altenberg. In: Dahm, C.Lobbedey, U.-Weisgerber, G., Der Altenberg: Bergwerk und Siedlung aus dem 13. Jahrhundert im Siegerland. Band 1. Die Befunde. Denkmalpflege und Forschung in Westfalen. Band 34, 21-31. Bonn.

LUGGIN, A., 2003: Archäobotanische Analysen der Pflanzlichen Makroreste aus dem Mittelalterlichen Bergbaurevier auf dem Kristberg, Gem. Silbertal. In: Mittelalterlicher Bergbau auf dem Kristberg im Montalfon Vorarlberg (Österreich) (Krause, R., ed.), 45-74. Bonn.

MAUR, E., 1984: Protirobotní bouře na Přísečnickém panství v letech 1664-1665, Ústecký sborník historický 1983, 219-228.

NÝVLTOVÁ FIŠÁKOVÁ, M.-PROCHÁZKA, R.-SŮVOVÁ, Z., 2016: Vyhodnocení osteologických pozůstatků z výzkumu parcel domů Dominikánská 11-19 a Kobližná 3 v Brně. K otázce organizace zásobování měst masem ve vrcholném středověku, PV 57, č. 2, 95-176.

RICHTER, M., 1982: Hradišt'ko u Davle, městečko ostrovského kláštera. Praha. 
ROUS, P., 1998: Středověké hornické sídliště neznámého jména u Havlíčkova Brodu na k. ú. Termesivy. In: Stř́ibrná Jihlava 1998, 102-115. Jihlava - Havlíčkův Brod.

- 2001: K závěrečné fázi vrcholně středověkého hornictví na Havlíčkobrodsku. In: Stř́ibrná Jihlava 2001, 66-81. Jihlava - Pelhřimov - Havlíčkův Brod.

- 2004: Stříbrorudné hornictví na Havlíčkobrodsku od 13. do 17. století, Archaeologia technica 15, 49-58.

RÖSCH, M. a kol., 1994: Rösch, M.-Karg, S.-Sillmann, M., Vierhundert Jahre gelagert: Pflanzenreste in Decken und Wänden. Botanische Dokumente zu Ernährung, Landwirtschaft und Landschaft aus der Langen Straße 49. In: Hausgeschichten. Bauen und Wohnen im alten Hall und seiner Katharinenvorstadt. Kataloge des Hällisch-Fränkischen Museums Schwäbisch-Hall 8 (Bedal, A.-Fehle, I., edd.), 475-491. Sigmaringen.

SCHNEIDERWINKLOVÁ, P., 2000: Sídelní a těžební aktivity v areálu Kašperských Hor. Nepublikovaná diplomová práce, Katedra archeologie ZČU, Plzeň.

SCHUBERT, M.-WEGNER, M., 2015: Die Grabung Roter Hirsch - Hochmittelalterliche Wohn- und Werkstätten der Dippoldiswalder Bergleute - Archeologický výzkum Roter Hirsch - vrcholně středověké sídliště a pracovní areál horníků z Dippoldiswalde - The excavation Roter Hirsch - high mediaeval dwellings and workshops of the Dippoldiswalde miners. In: ArchaeoMontan 2015. Montanarchäologie im Osterzgebirge - Montánní archeologie ve východním Krušnohoří. Arbeits- und Forschungsberichte zur sächsischen Bodendenkmalpflege. Beiheft 30 (Smolnik, R., ed.), 207-244. Dresden.

SCHUBERT, M.-WEGNER, M.-HERBIG, CH., 2014: Die Grabung Roter Hirsch - Erste Ergebnisse zur hochmittelalterlichen Siedlung der Dippoldiswalder Bergleute - Archeologický výzkum lokality Roter Hirsch - první výsledky studia sídliště středověkých horníků z Dippoldiswalde. In: ArchaeoMontan 2014. Ergebnisse und Perspektiven - Výsledky a výhledy. Arbeits- und Forschungsberichte zur sächsischen Bodendenkmalpflege. Beiheft 29 (Smolnik, R., ed.), 215-221, 228-231. Dresden.

SCHWABENICKY, W., 2009: Der mittelalterliche Silberbergbau im Erzgebirgsvorland und im westlichen Erzgebirge. Chemnitz.

SKRUŽNÝ, L., 1980: Několik poznámek k otázce vývoje a funkce pece ve slovanských, středověkých a novověkých objektech i mimo ně, AH 5, 221-242.

SOMER, T., 2016: Pohledský urbář (kolem roku 1328), Havlíčkobrodsko. Sborník příspěvků o historii regionu 30, 7-38.

STEUER, H.-GOLDENBERG, G., 2002: Bergbausiedlungen des Mittelalters im südlichen Schwarzwald. In: Interdisziplinäre Beiträge zur Siedlungsarchäologie. Gedenkschrift für Walter Janssen. Internationale Archäologie. Studia honoraria 17 (Ettel, P.-Friedrich, R.-Schier, W., edd.), 403-423. Rahden/Westfallen.

STOPP, B., 2003: Tierknochenfunde und zur Ernährungsstrategie der mittelalterlichen Bergleute auf dem Kristberg. In: Rüdiger Krause: Mittelalterlicher Bergbau auf dem Kristberg im Montafon, Vorarlberg (Österreich). Frankfurter archäologische Schriften, 75-88. Bonn.

STRASSBURGER, M., 2015: Montanarchäologie und Wirtschaftsgeschichte des Bergbaus im Schauinsland vom 13. Jahrhundert bis um 1800. Universitätsforschungen zur prähistorischen Archäologie. Band 275. Bonn.

ÚLEHLOVÁ-TILSCHOVÁ, M., 1945/2011: Česká strava lidová [reprint]. Praha.

VELÍMSKÝ, F., 2007: Nově evidované středověké montánní aktivity na Kutnohorsku - Neu entdeckte Spuren alten Bergbaus bei Kutná Hora (Kuttenberg). In: Stř́ibrná Jihlava 2007, 90-101. Jihlava.

- 2012: Zaniklý těžební areál U Všech Svatých na Horách Kutných - Desserted mining site U Všech Svatých (Allerheiligen/All Saints) near Kutná Hora (Kuttenberg), Acta Rerum Naturalium - Př́rodovědný časopis Vysočiny 12, 203-209.

VELÍMSKÝ, F.-KONČELOVÁ, M., 2012: Archeologický výzkum zaniklého těžebního areálu u kostela sv. Václava v Pněvicích (okr. Kutná Hora) - Archaeological research of desserted mining area near the church of St. Wenceslaus in Pněvice (Pnewitz, district Kuttenberg), Acta Rerum Naturalium - Př́rodovědný časopis Vysočiny 12, 253-256.

VIERECK, S., 1998: Die Textil- und Lederfunde. In: Dahm, C.-Lobbedey, U.-Weisgerber, G., Der Altenberg. Bergwerk und Siedlung aus dem 13. Jahrhundert im Siegerland. Band II., 113-157. Bonn.

WALDHAUSER, J. A KOL., 1993: Waldhauser, J.-Daněček, V.-Nováček, K., Eine hochmittelalterliche Aufbereitungslage für goldhaltige Erze im Bergbaurevier von Kašperské Hory (Bergreichenstein) in Böhmen. In: Montanarchäologie in Europa. Berichte zum internationalen Kolloquium „Frühe Erzgewinnung und Verhüttung in Europa“ in Freiburg in Breisgau vom 4. bis 7. Oktober 1990 (Steuer, H.-Zimmermann, U., edd.), 391-400. Sigmaringen.

ZIMOLA, D., 2012: Hornická sídliště v okolí Jihlavy podle archeologických pramenů - Mining settlements around Jihlava according to archaeological recources, AVV 3, 27-57.

ŽEMLIČKA, J., 2011: Přemysl Otakar II. Král na rozhraní věků. Praha.

- 2014: Království v pohybu. Praha. 


\section{Zusammenfassung}

Zur Frage der Landwirtschaft und Nahrungsmittelproduktion mittelalterlicher Bergbaukommunitäten

\section{Einleitung}

\section{Was ist das, mittelalterliche Bergbausiedlungen?}

Bergbausiedlungen sind prosperierende Siedlungen von Bevölkerungsgruppen, deren Status berufsbezogen definiert wurde. Ihre Gründung hat mit nach der Mitte des 13. Jahrhunderts erfolgten Bergbauaktivitäten ihren Höhepunkt. Die Frage ist die Versorgung mit Nahrungsmitteln und der jeweilige Anteil der Eigenproduktion. Die vorliegende Studie arbeitet mit Bergbauarealen auf přemyslidischen Gebieten, die einer archäologischen Untersuchung unterzogen wurden. Die erste Region ist die Böhmisch-Mährische Höhe (Abb. 2, Abb. 5-8). Das zweite Gebiet ist das Erzgebirge (Abb. 3, 4, 9-10).

\section{Das topographische Bild von Bergbauwüstungen}

Bei den Bergbausiedlungen finden wir keinen Grundrisstyp, der für Agrarsiedlungen typisch wäre. Bergbausiedlungen erscheinen in der Flur nicht als deren integrales Element. Anzeichen für eine orthogonale Anordnung beobachten wir an der Fundstelle Kremsiger (Abb. 4, 9-10). Auf der Böhmisch-Mährischen Höhe ordnen wir Vyskytná und Buchberg den Siedlungen mit einer Linienanordnung entlang von Gruben zu. (Abb. 7 und 8). Am Ende des Spektrums befinden sich Areale ohne Anordnung. Diesem Bild nähert sich Staré Hory.

Form der Behausungen und Fehlen einer landwirtschaftlichen und sanitären Infrastruktur

Die häufigsten Reste von Bauten sind eingetiefte Strukturen (Abb. 11-15). Zweifellos spielten sie bei den Rohstoffverarbeitungsprozessen und metallurgischen Tätigkeiten eine Rolle, sie dienten als Lager, wesentlich ist aber ihre Wohnfunktion. Die Typen der Bauten sind bereits vom Wesen der Sache her spezifisch, und man kann nicht sagen, dass sie zeitgenössischen städtischen oder dörflichen Baukonstruktionen entsprechen.

\section{Quellen zur Landwirtschaft und Nahrungswirtschaft von Bergbausiedlungen}

\section{Versorgung, Nahrungswirtschaft und Landwirtschaft von Bergbauzentren in den schriftli- chen Quellen}

Einige Informationen über die Versorgung können die in den Dokumenten des 13. und 14. Jahrhunderts enthaltenen Grundsätze über Einrichtung und Regulierung verraten. Auf jedem Grubenmaß konnten 16 Behausungen angelegt werden, wobei in einem, zwei oder mehr Bauten eine Fleischerei, eine Bäckerei und ein Bad eingerichtet werden können. Dort kann es einen Bier-, Met- und Weinausschank geben (Tomaschek 1897, 46-47, Nr. 84 und 86). Interessant ist die Angabe, dass sich die Bergleute zu den Behausungen in Reichweite eines Bogenpfeilschusses auch Weideflächen für Vieh anlegen konnten (CIB I, 328).

\section{Frage nach der Lagerung und Wärmebearbeitung von Lebensmitteln in archäologischen Bergbausiedlungen}

In Bergbausiedlungen begegnet man nur selten Vorratsgruben. In Staré Horé gibt es in den Innenräumen Keller (Abb. 11-12). Eine Abweichung ist das geringe Vorkommen von Vorratsbehältern. Ein Interpretationsproblem stellen Ofenreste in Grubenhäusern dar (Abb. 13 und 14). Eine weitere Gruppen sind Feuerstellen in den Grubenhäusern. Bei ihnen kann man eine Zubereitung der Speisen in Betracht ziehen, ausgenommen Backen von Brot. Eine weitere Gruppe sind Öfen und Feuerstellen auf Geländeniveau (Abb. 15). 


\section{Bergbausiedlungen, Getreide und Getreidewirtschaft: Aussage der Archäologie und der Archäobotanik}

In der im Erzgebirge liegenden Bergbausiedlung in Dippoldiswalde wurde Roggen, Saatweizen und Saatgerste, ferner Sellerie, Erbsen, Mohn und Flachs entdeckt (Schubert a kol. 2014, 201-202). In Starý Zámek gab es Makroreste mit Roggen, Saatflachs und Saatdotter. Das Vorkommen von thermophilen Unkräutern (Rundblättriges Hasenohr, Acker-Haftdolde, Einjähriger Ziest) deutet auf den Import von Früchten aus Niederungen hin. Ein breiteres Fruchtspektrum wurde in den Pollen entdeckt, und zwar Roggen, Hafer, Gerste, Flachs, Hanf/Hopfen. Der Pollen spiegelt jedoch nicht die lokale Produktion wider, denn er stammt von Fäkalien (Abb. 20-23). In Cvilínek wurden in Makroresten anspruchslose Arten wie Hafer, Gerste, Saumroggen und Saatflachs festgestellt. Ein unterschiedliches Bild bietet Staré Hory, das ein dicht bevölkerter Großbetrieb war. Die Getreide stellen 43,5\% dar. Dort vertreten war Gerste, Saatroggen und gemeiner Buckelweizen. Festgestellt wurde Getreidereinigungsabfall in Form von Ährenspindelgliedern von Weizen und Gerste, was auf einen lokalen Getreideanbau hindeutet. Von den Hülsenfrüchten wurde der Samen von thermophilen Linsen gefunden, was mit dem Fund von Saathirse den Import aus freundlicheren Gebieten andeutet.

\section{Obst und wilde Nutzarten: eine potenzielle Nahrungsergänzung}

Eine Quelle der Nahrungsergänzung waren Waldfrüchte, wir finden besonders Haselnüsse. Eine Schlüsselbedeutung für die Ernährung hatte auch die Mast mit Eicheln. Im 16. Jahrhundert gehören in Osteuropa Eicheln, Nüsse und Buchweizen zu den herrschaftlichen Rationen. Eichenund Buchenwälder werden im Mittelalter als Weideflächen unterhalten. In den Makroresten in Staré Hory ist auch der Holunder belegt, aus dessen Beeren man Mus, Brei und Soßen kochte. Das Vorhandensein der Birke in on-site/off-site-Aufzeichnungen lässt auch die Gewinnung von Saft als sog. Zuckerquelle zu. Eine andere Quelle dafür waren auch Himbeeren und Brombeeren, die ebenfalls an den meisten Fundstellen belegt sind. Blätter des Wiesen-Sauerampfers und des Krausen Ampfers dienten als Speisezusätze (Úlehlová-Tilschová 1945/2011, 16-57). In Cvilínek waren Apfelbäume, Vogel-Kirschbäume und Haselnusssträucher, Himbeer- und Brombeersträucher belegt. Funde von Zwetschgen, Nüssen und Waldfrüchten sind uns auch von der Siedlung Kristberg bekannt (Luggin 2003, 71-72).

\section{Das archäologische Bild der Tierwelt in mittelalterlichen Bergbausiedlungen}

Für Bergbausiedlungen ist ein geringes Vorkommen osteologischer Funde typisch. Der Fundkomplex von Staré Hory enthielt $1 \%$ Pferde, aber auch 862 Fragmente von großen Huftieren, vielleicht Mauleseln, Mulis u.ä. Am meisten vertreten war das Hausrind (57\%). An einem Zehenglied wurden auf Überbelastung des Tieres zurückzuführende pathologische Veränderungen entdeckt. Bei den Huftieren beobachten wir nur ausgewachsene Exemplare. Ein weiteres Tier war das Hausschwein (32\%). Es wurden 76 Knochenfragmente von Schafen/Ziegen (6\%) entdeckt. Achtundzwanzig Fragmente gehörten zu ausgewachsenen Haushühnern und zehn Fragmente zu Küken (3\%). In einem Fall war eine ausgewachsene Hausgans vertreten. Ein Übergewicht von ausgewachsenen Exemplaren ist beim Hausrind offensichtlich, beim Schwein überwiegen umgekehrt nicht ausgewachsene. An 15\% der Knochen befinden sich Schnitt- und Hackspuren, vor allem beim Hausrind und bei großen Huftieren. Weniger zerlegt wurden mittelgroße Säugetiere. Es wurden auch Brandspuren an den Knochen festgestellt, die vom Braten, aber auch vom Verbrennen verendeter Exemplare stammen könnten. Dies war am meisten an den Knochen von großen Huftieren, weniger beim Hausrind, Schwein, und an den Knochen mittelgroßer Säugetiere der Fall (Sůvová 2012). An den Fundstellen Kremsiger und Starý Zámek stellen Knochen und Zähne des Hausrinds und größerer Säugetiere über die Hälfte des Fundkomplexes (Kyselý 2015). In Kremsiger handelt es sich um junge Einzeltiere. In der Siedlung folgt ihnen zahlenmäßig das Schwein, an Hüttenplätzen Pferde (Abb. 24-26). 


\section{Diskussion und Schlussfolgerungen}

Überlegungen zu weiteren Umständen bzgl. der schwachen Stellung einer eigenen Getreidewirtschaft in Bergbauzentren

Oberhalb der Höhengrenze für Getreidewirtschaft lagen nur Siedlungen wie Kristberg (1 $190 \mathrm{~m}$ ), Brandes en Oisans (1 $800 \mathrm{~m}$ ), ggf. Schauinsland (1 $100 \mathrm{~m}$; Abb. 18). Trotzdem beobachten wir überall eine schmalere Zusammensetzung von Halmfrüchten. Hauptgrund für die Nichtexistenz der Getreidewirtschaft war die Grenze zwischen einer speziellen Nutzung des Bodens im Zusammenhang mit dem Bergbau und zwischen den Besitzverhältnissen der Bodenflächen: die Bewohner von Bergbausiedlungen waren weder Eigentümer noch Pächter von Agrarboden und hatten kein Recht ihn zu bestellen.

\section{Belege für das Vorkommen von Tieren und die Frage nach eigener Tierhaltung und Tierproduktion}

Das Übergewicht von Tierhaltung über Getreidewirtschaft wird in Erwähnungen von Weideland angedeutet. In Bergbausiedlungen muss auch eine Masttierhaltung von Zug- und Lasttieren in Betracht gezogen werden. In den osteologischen Funden können wir zwischen Schlachtproduktion und Versorgung nicht unterscheiden. Bei ausgewachsenen Pferden, Huftieren und dem Hausrind muss auch von ihrer Nutzung als angespannte Zugtiere bzw. auch als Lasttiere ausgegangen werden. Bei den ausgewachsenen Exemplaren weiterer Tiere (mit Ausnahme des Schweins) kann man auch davon ausgehen, dass sie zur Gewinnung von Milch und Wolle gehalten wurden. Nachdem sie ausgedient hatten oder verendet waren, wurde Fleisch, Haut, Knochen, Hörner und Hufen aller Exemplare verwertet. Bedeutend war die Herstellung von Talg für Lampen (Doležalová 2012).

\section{Bergbausiedlungen, Landwirtschaft und der Markt}

Läden und der Markt werden für gewöhnlich als Beleg für den städtischen Charakter von Bergbausiedlungen angesehen, was jedoch ein Nichtverstehen ihres prosperitären Charakters ist. Für die Versorgung mit Agrar- und Lebensmittelerzeugnissen kam dem örtlichen Markt eine Schlüsselrolle zu. Das Verhältnis dieser Quellen hing von der jeweiligen Größe der Kommunitäten, den natürlichen Bedingungen und der Dichte der Agrarbesiedelung ab. Die Ernährungesstrategien wurden miteinander kombiniert.

\section{Bürger als Inhaber von Verleihungen, von Agrarboden und als Bergbeamte in der Nähe von Grubenzentren}

Mit der Beherrschung des Marktes durch Bürger hängt die Versorgung der Läden zusammen. Boden in der Nähe von Gruben und in der Hand von Bürgern können wir in seiner entwickelten Phase im sog. Großen Privileg von Brod aus dem Jahre 1278 beobachten. Den Besitz von Boden deutet in diesem Sinn auch eine Urkunde aus dem Jahr 1252 für einen Münzmeister Heinrich an, der in der Region Humpolec Land erhielt, um darauf Hufe abzustecken und Kolonisten anzusiedeln. Man kann darüber diskutieren, ob es hierbei um Ankäufe von Bürgern auf dem Land oder um praktische Gründe geht. In den Anfangsphasen des Abbaus in den Gebieten, in denen die Infrastruktur und der Markt erst im Entstehen begriffen war, stand der Münzmeister vor der Aufgabe, die Grubentätigkeit in Gang zu bringen und was materielle und menschliche Ressourcen betrifft zu organisieren. Das war mit dem Zuzug von Menschen verbunden, deren Verpflegung und Versorgung gewährleistet werden musste.

doc. Mgr. Petr Hrubý, Ph.D., Ústav archeologie a muzeologie Filozofické fakulty Masarykovy univerzity, Arna Nováka 1, 60200 Brno, Česká republika, PetrSilberbergbau@seznam.cz

MUDr. Mgr. Kryštof Derner, Ústav archeologické památkové péče severozápadních Čech, v. v. i., J. Žižky 835, 43401 Most, Česká republika,kderner@seznam.cz 
